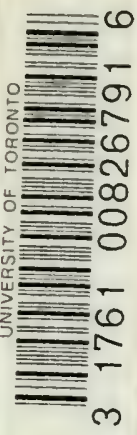

Eritish Mascum (Natura] Historil Deut, of Zoology

Gui? z to the Moliusca 


\section{PRESENTED}

BY

The Trustees

OF

THE BRITISH MUSEUM. 


\section{GUIDE}

\section{TO THE MOLLUSCA}

EXHIBITED IN THE

ZOOLOGICAL DEPARTMENT,

BRITISH MUSEUM (NATURAL HISTORY).

ILLUSTRATED BY 47 FIGURES.

LONDON :

PRINTED BY ORDER OF THE TRUSTEES

OF THE BRITISH MUSEUM.

Sol.d at The Britisi Museum (Natural History), Cromwell Road, S. W. 7 AND BY

B. Quantrci, Ltd.; Dulau \& Co., Lto.;

The Oxfurd University Press; Wireidon and Wesley, Lid, London; and Oliver and Boyd, Edinburom.

1923. 



\section{GUIDE}

\section{TO THE MOLLUSCA}

EXIHIBITED IN THE

ZOOLOGICAL DEPARTMENT, BRITISH MUSEUM (NATURAL HISTORY).

ILLUSTRATED BY 47 FIGURES.

LONDON :

PRINTED BY ORDER OF TIIE TRUSTEES

OF THE BRITISH MUSEUM.

Gold at Tie British Meseu Nateral History), Croswell Roai, S. W. 7.

AXD BY

B. Quarticit, Lto.; Dulau \& Co., Lto.;

The Oxford Universty Press; Wreldox axd Wesley, Lth., London;

and Oliver axd Boyd, Edineurgh.

1923.

[All rights reserved] 


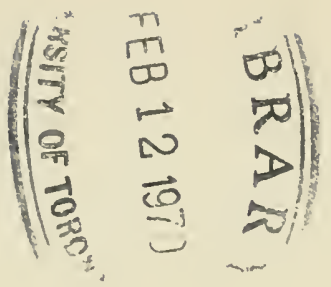

PRINTED IN ENGLAND

AT THE OXFORD UNIVERSTY PRESS BY FREDERICK IIALL

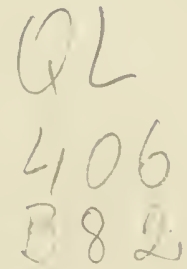




\section{PREFACE.}

OxE of the large galleries to the north of the Bird Gallery is devoted to the exhibition of the Mollusea. This extensive group includes nearly 60,000 living species; most of these are represented in the Huseum Collection, which consists of over 600,000 specimens. Models or spirit specimens of examples of all the prineipal divisions are exhibited, and the models of an Octopus and of the Giant Squid are the most eonspicuous objects in the Gallery. The shells of molluses are a favourite objeet of study and a souree of pleasure to eollectors, and the exhibition of shells has been made as complete as possible, so as to be adequate for the requirements of the majority of students and visitors. The shells are arranged in systematic order in the series of table-cases; in addition a separate series of British Shells is displayed in some table-eases near the west wall, and an instruetive exhibit, prepared by Mr. B. B. Woodward, illustrating the modifieations of structure, form, sculpture, \&e., in the shells of Mollusca is placed in wall-cases on the same side of the Gallery.

This Guide-book has been prepared by Mr. G. C. Robson, M.A. It is to a large extent based on the late Mr. E. A. Smith's eontribution to the old Guide to the Shell and Starfish Galleries, but it has been rewritten and much new matter has been introduced.

Thanks are due to Messrs. A. \& C. Black, Messrs. Macmillan \& Co., and Crosby Lockwood \& Son, for kindly allowing the use of clichés from illustrations in various works published by them.

British Meseum (Nitural History),

C. TATE REGAN, Keeper of Zoology.

Loxpox, S.W. 7.

I Iarch 1923. 
CONTENTS.

INTRODUCTION

General

Classification

Structure

Reproduction and Development Habits .

Distribution

Variation

Economic Importance

AMPHINEURA .

GASTROPODA .

SCAPHOPODA .

LAMELLIBRANCHIA

CEPHALOPOD
PAGE

5

5

7

8

12

13

15

16

17

$1 !)$

20

35

INDEX TO PRINCIPAL FAMILIES AND GENERA . 53 


\section{GUIDE TO THE MOLLUSCA.}

\section{INTRODUCTION.}

\section{General.}

The Mollusea constitute one of the phyla, or principal divisions of the Animal Kingdom, and include such forms as the Whelk, Snail, Slug, Oyster, and Octopus. They are distributed all over the world and are to be found in the sea, in fresh water, and on land.

The phylum is very sharply defined and its relationships are obscure : it would seem to have some distant affinity with the Annelida or segmented worms.

Although such animals as the Snail, the Oyster, and the Octopus may, at first sight, appear to have little in common, all Iollusca nevertheless resemble one another in the fundamental plan of their structure. They are soft-bodied, unsegmented, invertebrate animals with a muscular projection on the under side, the "foot", which serves for locomotion, and with the skin of the back, the 'mantle', overhanging at the sicles as a flap or fold, the space beneath which is known as the mantle-cavity. The mantle nearly always seeretes a calcareous shell, and the organs of respiration, whether gills or lung, are usually situated in the mantle-carity. The Hollusca have a heart and blood-ressels, a complex nervous system, and, in all those that have a definite heard, a characteristic rasping organ, the 'radula', within the mouth.

This definition leaves out of account certain highly specialized and parasitic Mollusea in which the structures mentioned are not found in the adult, although they, or their rudiments, may be present in the young.

The shell is the most striking feature of most Mollusca, and the various forms it assumes provided a basis for the older elassifications of the group. It is in one piece (univalve) and nearly always spirally coiled in the Gastropoda (Snails, Slugs, Whelks, and the like); of two pieces (bivalve) in the Lamcllibranehia (Oysters, Mussels, Cockles, \&e.) ; and eoncealed within the soft tissues in nearly all existing Cephalopoda (Squids, Octopus). The vast majority of Mollisea belong to one or other of these three great divisions, but a few remain over which are grouped as 
Amphinemra (C'hitons or 'coat-of-mail' shells) and S'caphopoch ('Tusk-shells).

Certain animals belonging to other divisions of the Animal Kinglom hare shells that resemble more or less closely those of Fia. 1.

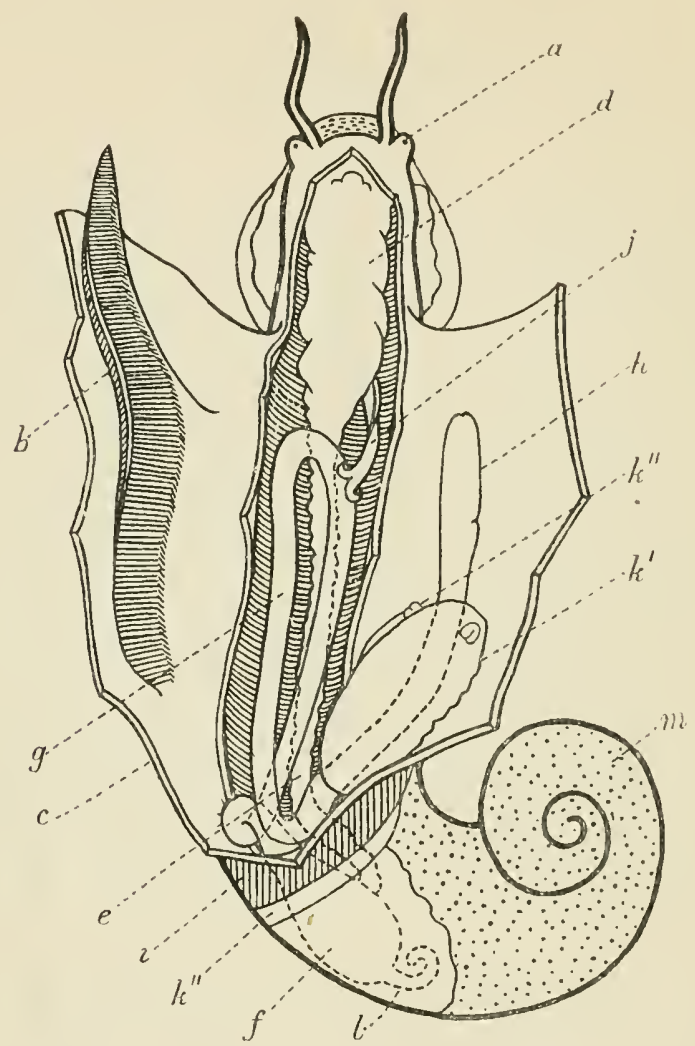

General anatomy of Trockus $(\times 3)$ showing the position of some of the more important organs.

$a$. eye ; $b$. gill ; $c$. cut edge of mantle ; $d$. erop ; $e$. oesophagus : $f$. stomach ; $g$. intestine $: h$. rectum; $i$. pericardium; $j$. radula sac; $k^{\prime} k^{\prime \prime}$. lidneys; $l$. liver ; m. genital gland.

Mollusca, and were, therefore, associated with the latter by the older naturalists. Such are the Lamp-shells (Brachiopoda), which superficially resemble Lamellibranchs but differ widely in their internal structure, and the Barnacles (Cirripedia), which are greatly modified Crustacea. 
CHASSIFICATION.

A table of the main divisions of the Mollusca according to the system of classification-adopted in the arrangement of the gallery is given below. The names of a few typical genera are mentioned as examples under each of the orders.

\section{Phylum MOLLUSCA.}

Class I. AIPHINEURA.

Order 1. Polyplacophora: Chilon.

2. Aplacophora: Neomenia, Chactoderma.

Class II. GASTROPODA.

Sub-elass I. Strreptoneura

Order 1. Aspidobranchia :

Patella (Limpet), Haliotis (Ormer), Turbo (Topshell).

2. Pectinibranchia :

Littorina (Periwinkle), Vivipara (River Snail), Cypraea (Cowry), Buccinum (Whelk), Carinaria (Heteropoda).

Sub-class II. Euthrneura.

Order 3. Opisthobranehia :

Bulla (Bubble-shell), Aplysia (Sea-Hare), Nudibranchic (Sea-Slugs), Clione (Pteropoda or Sea-Butterflies).

4. Pulmonata :

Siphonaria (False Limpet), Limnaea (W'Tater Snail), Helix (True Snail).

Class III. SCAPHOPODA.

Dentalium ('Tusk-shell).

Class IV. LAMELLIBRANCHIA.

Order 1. Protobranchia: Nucula.

2. Filibranchia: Mytilus (Mussel), Pecten (Scallop).

3. Eulamellibranchia: Ostruea (Oyster), Cardium (Cockle), Teredo (Shipworm).

4. Septibranchia: Cuspidaria.

Class $V$. CEPHALOPODA.

Order 1. Tetrabranchia: Nautilus, Ammonites.

2. Dibranchia: Loligo (Squid), Sepin (Cuttlefish), Polypus (Octopus). Belemniles. 


\section{S'TRUCTURE.}

In nearly all the Mollusea the body is divisible into three main regions, the head, the foot, and the visceral sae which is covered by the mantle. In the Lamellibranchia the head is hardly developed at all, while in the Cephalopoda it is surrounded by

Fis. 2.

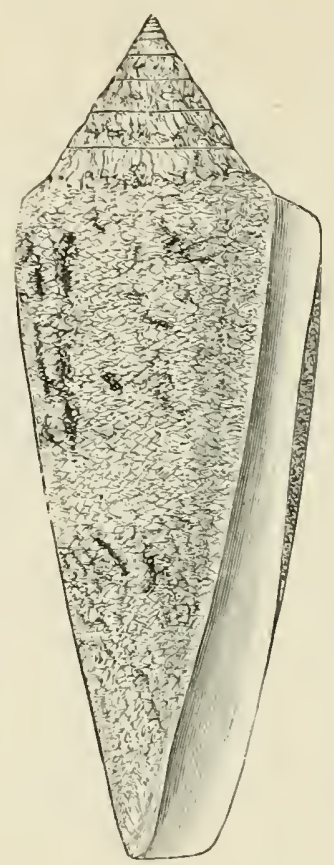

The 'Glory-of-the-Sea' Cone (Conus glorin-maris). Case 94.

(From the Philippine Islands.)

and coalesced with the foot, the edges of which form a circle of sucker-bearing arms.

The foot is varionsly modified for creeping, digging, and other purposes. In the Pteropoda or Sea-Butterflies the sides of the foot are expanded to form large fins.

The term mantle is sometimes restricted to the out-growing folds at the sides of the body. but is more correctly applied to the entire corcring of the visceral sac. The free folds may be restricted in extent by coalescence with the body, and the cavity they enclose may this vary greatly in size and position. 
The shell is secreted by the outer surface of the mantle, but may be enveloped by the mantle so as to become partly or altogether an intermal strueture. It is formed of a horny substance (conchiolin) impregnated with carbonate of lime. As a rule two layers can be distinguished, differing in their minute strueture and in their mineralogieal constitution. In the onter or prismatic layer, which forms most of the thickness of the shell, the carbonate of lime is in the form of ealcite. In the inmer or nacreous layer ('mother-of-pearl') it is in the hareler form of aragonite. An outer skin (periostracum) is frequently present. In some molluses the mineral constituents are redued or absent and the shell is 'homy' and flexible, and in some others the shell is entirely absent.

There are one or two exceptions to the rule that molluscan shells are seereted by the mantle. In the Cephalopod Argonauta, as will be explained later, a spiral shell is produced by secretion

FIs. 3.

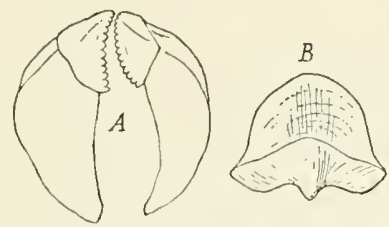

Mandibles of Gastropoda. A. Janus; B. dorsal mandible of Aegirus. From Lankester's Treatise of Zoology (by permission of Messrs. A. \& (. Black).

from two of the arms, while the under surface of the foot secretes a calcareous plate in the Gastropod Hipponyx. The modifieations of the shell in the various elasses will be described in the systematic survey (p. 19), but the visitor's attention may here be called to the exhibit in Wall-case $A$, where the main points of shell-structure and the more remarkable changes of form throughout the phylum are illustrated.

Although the shells of many families are highly charaeteristic, there are several examples of molluses of widlely different strueture and systematic position that have shells resembling each other, and classifications based on the shell are subject to change with increasing anatomical knowledge.

Certain molluses have internal skeletal struetures. The head cartilages of the Cephalopoda and the cartilaginous supports of the radula in the Gastropoda are of this nature.

The alimentary canal is usually differentiated into a mouth, pharynx, oesophagus, stomach, and intestine. The liver opens by one or more ducts into the stomach, and salivary glands are invariably present. 'The names 'liver' and 'salivary glands' 
must not be taken to imply that their secretions are of exactly the same nature as thesereretions of these organs in the Vertebrates.

Horny jaw-plates (mandibles). which may be paired or single, are fomnd in all molluses except Lamellibranchs and most of the Amphincura.

Behind these jaw-plates is the radula, which is generally present except in the Lamellibranchia. This is a tongur-like organ beset with numerous transverse rows of minute teeth. 'The form and arrangement of the teeth are highly characteristic, and in the Gastropocla they have been made the basis of the classification of part of the group.

In some Gastropoda and most Lamellibranchia a second characteristic structure, the crystalline style, is found in the stomach or in a sac at the junction of the stomach and the intestine. It is a more or less elongated rod of semi-gelatinous substance. It is believed to provide a rligestive ferment.

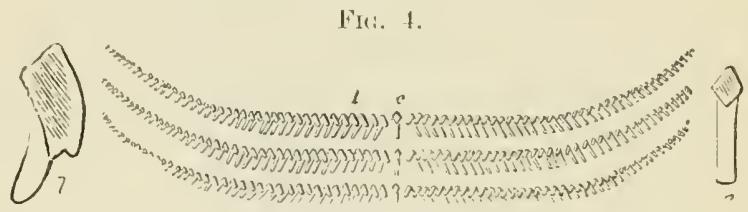

Three rows of Teeth of the Radula of Siphonaria. c. central; l. lateral teeth.

The circulatory system consists of a heart composed of a ventricle and one or more auricles, blood-ressels, and blood sinuses. The last are large, irregular spaces in the connective tissue between the various organs and may possibly represent in part the eapillary system of other animals. The blood is usually colourless, but in certain cases it is red or blue owing to the presence of haemoglobin or of haemocyanin.

The respiratory organs of the Mollusea are usually gills, but in certain cases these are replaced by other organs. The typical gills (etenidia) consist of a number of filaments or flattened plates arranged along a main axis and suspended from the roof of the mantle-cavity. Important modifications of the gills occur in the Lamellibranchs. In many molluses the gill is lost and the mantlecavity is adapted as a lung for breathing air ; in others the typical gills are suppressed and "false gills" are developed from the mantle, whilst in a few there are no gills at all and respiration is carried on by the general surface of the body.

The nervous system consists of several pairs of ganglia, nervecords and sense-organs. The most important ganglia are the cerebral, the pedal, the pleural, and the visceral. These are joined in various ways by connecting cords ("commissures "). 
Although there is no brain in the strict sense of the worel there is sonnetines a coneentration of ganglia at the anterion (") which may become so intimate as to comstitute a solict mass.

A consiclerable variety of sense-ergans is juesent, of which we can only mention the principal ones.

Eves, of greater or less complexity, are dercloped, most often in the region of the head, but sometimes on the mantle. 'The

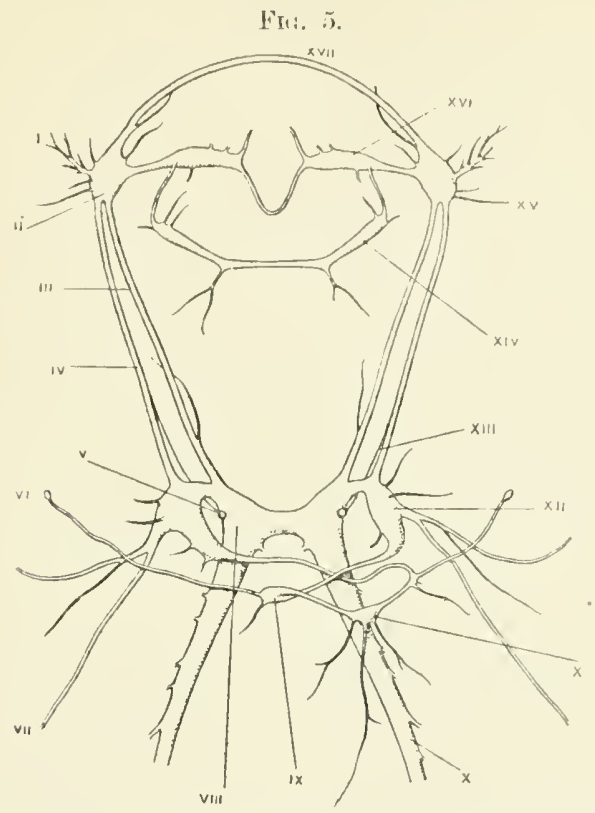

Central nervous system of Patella vulgata, dorsal aspeet.

I. tentacular nerve; II. cerebral ganglion; III. ecrebro-pedal comnective: Iv. cerebro-pleural connective; vil, pedal ganglion: $\mathrm{x}$. visceral commissure: XI. abdominal ganglion; XIr. pallial ganglion; XIV. stomatogastric ganglion; Xiri. ecrebral commissure.

Erom Lankester's Treatise on Zoology (by permission of Hessr's A. \& (. Black).

remarkable eyes of some Cephalopoda rival those of Vertebrates in the claboration of their structure.

Organs of smell (osphradia, rhinophores) are found on the head or, in aquatie forms, at the entrance to the mantle-cavity, near the gills.

Otoeysts are found in most molluses in the tissues of the foot. They may, as was formerly believed, be organs of hearing, but they are more probably connceted with the sense of balance and direction. 
Renal organs (kidneys) are found in all molluses, usually in intimate connexion with the pericardium and reproductive organs. In eertain forms they act as genital ducts as well as kicheys. In general strueture they are glandular saes, the walls of which are inereased by extensive folding. The liver sometimes acts as an exeretory organ, and eertain of its cells may be specialized for that purpose.

The genital duets may be simple or may have an elaborate apparatus of accessory glands and other organs. In the Aplacophora and certain Gastropoda there are no genital ducts and the germ cells are liberated through the renal ducts.

\section{Reproduction and Development.}

The seres are usually separate, but hermaphroditism occurs in nearly all the classes, and the Euthyneura anong the Gastropoda are exelusively hermaphrodite. In a few molluses the aninal passes through a regular sexual eycle, being male at one periorl and female at another. This oceurs in the Limpet (Patella), in Crepidula and probably in Aplysia among Gastropoda, and in the Common Oyster among Lamellibranchia. Hermaphrodite species are usually cross-fertilized, but self-fertilization sometimes oceurs. Only one case of parthenogenesis is known, that of the Gastropod Paludestrina jenkinsi. The males and females of bisexual forms are sometimes distinguished by the size and shape of their shells.

Fertilization is either external or internal. The former is usually the rule among marine forms, in which the number of eggs discharged from the ovary may be enormous, the Common Oyster depositing as many as $60,000,000$. In most aquatic Mollusca the young pass through a series of free-swimming larval stages. The first stage is usually that known as the Trochosphere, whieh resembles very closely the earliest larval stage of certain Amnelid worms. Later a lobed swimming-organ, the velum, is developed and the larva is termed a Veliger. In all terrestrial molluses and in certain aquatic forms, such as some Cephalopoda, the eggs are few and large and develop direetly, the larval stages being sujpressed.

The large eggs of some terrestrial molluses mayhave a calcarcous shell. In numerous cases the eggs are laid in clusters or in ribbons, which take on various shapes (Wall-eases B and E).

There is a great variety of parental care among Mollusea, from a mere temporary association with the parent, as in some Gastropods in which the eggs are laid on the shell, to contimuous incubation in special brood-pouches in the mother's body as in the Pond-Snail Vivipara. In certain Lamellibranchiathe Unioniclae, Cyrenidae, \&e.- the young are incubated between 
the gill lamellae, while the Paper-Nautilus, Argonauta, secretes a special shell from the dorsal tentacles, in which the young develop.

Special courtship habits are not unknown among Mollusca, and in the common Slugs (Limacidae) and Snails (Helicidae) these proceedings may be prolonged and complicated.

\section{HABITS.}

The Mollusca are characteristically slow-moving and 'sluggish', but nearly all have some power of locomotion, by swimming, crecping, or burrowing. The Cephalopoda are active and powerful swimmers.

The number of forms which are actually fixed down is very small. A good many Lamellibranchs may be temporarily anchored, but some, like the Oyster, are permanently attached by the shell.

The museular strength of some Molluses is known to be very great. The Common Limpet, for example, can resist a pull of (i2 lb.

The food of Mollusea and their methods of feeding are very varied. Where a radula is present it is generally used for rasping off portions of plant or animal tissues, but the Lamellibranchia and a few Gastropoda feed upon minute floating life (plankton) or on organic particles which are drawn in by the movements of vibratile hairs (eilia) on the gills and mantle. Those molluses that are definitely carnivorous generally prey upon sessile invertebrates such as the Coelenterates, Sponges, and Tunicates, or upon other Mollusea, but the active Cephalopods pursue and capture fishes and Crustacea.

Many molluses live in more or less close association with corals, Sponges, and other animals, although cases of actual parasitism are few. Some Gastropods are external parasites of Echinoderms, while a few Gastropods and Lamcllibranchs are highly degenerate internal parasites of Holothurians. In their turn, molluses are the hosts of very many external and internal parasites.

A remarkable instance of molluses that utilize for their own defence the organs of their prey is that of the Nudibranch Gastropods of the family Eolidiclae. These feed on Hydroids and other Coelenterates, and the stinging cells (nematocysts) of the latter are stored up in the dorsal appendages of the Eolicls, from which they are expelled when the animal is attacked.

Mollusea form the characteristic food of mumerous other animals. The Greenland Whale, which feeds upon plankton organisms, swallows vast quantities of Pteropods. Other whales, such as the Sperm Whale, live mainly on Cephalopods, and the beaks and other parts of these molluses may be found in their 
stomachs. Many fishes feed upon marine Gastropocls and I samcllibranchs. Sea-birds feed upon littoral forms between tidemarks and in coastal lagoons and backwaters. Petrels will seize and eat pelagic Cephalopoda. Land-Snails are eaten by numeroms birds, notably the 'Thrush, and also by mammals such as mice, badgers, and hedgelnogs. Crabs, lobsters, beetles, and starfish are among the invertebrate enemies of Mollusea. Young Lamellibranchs are said to be the exelusive food of the Annelid Magelona.

The age to which Mollusea live varies very eonsiderably. Precise figures are available for some Gastropoda and Lamellibranchia, and of these it appears that the latter may live longer. Certain freshwater Mussels (Anodonta) are said to reach the age of 20-30 years. The Common Oyster may live for 10 years. Of Gastropoda, Helix reaches the age of 6 or 7 years, Paludina 8 years, while the Common Periwinkle has lived in captivity for nearly 20 years. The beautiful Nudibranehs do not appear to be so long-lived as other Gastropoda. S'exual

Fig. if.

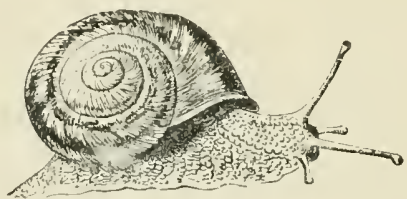

Helix desertorum. From Woodward's Manual of the Mollusca (by permission of Crosby Lockwood \& Son).

maturity in Gastropoda may be attained in the year of birth. The Common Limpet, Patella vulgata, is mature when less than an inch long. After that it eontinues to grow and sometimes attains a length of over $2 \frac{1}{2}$ inches. Two-thirds of its final size may therefore be developed after sexual maturity.

The resistance of Mollusea to adverse conditions is very marked. An Australian Pond-Mussel has been known to live out of water for over a year, and several Land-Snails have revived after a eaptivity of from two to five years without food. One of the most remarkable instances oceurred in the British Museum. A specimen of Helix desertorum, the eommon Desert Snail of Egypt, was fixed on a tablet in March 1846 and was found to be alive in March 1850, having passed four years in a museum case without any food or moisture. It beeame torpid in Oetober 1851 and was found to be dead in May 1852. Extremes of temperature appear to affect Mollusea less than some other animals. Thus a species of Helix has been said to tolerate a temperature of $-120^{\circ} \mathrm{C}$., and Melanopsis parreyssii lives at $42^{\circ} \mathrm{C}$. in hot springs in Hungary. 
Many Mollusea beeome torpid in winter in eold climates (hibernation) or in summer in hot climates (aestiration). Freshwater and terrestrial species in these ciremintanees bury themselves in the soil or shelter in crevices. The period of hibernation in the British Isles varies very much aceording to the severity of the weather, and Land-Snails may be found emerging from their retreat in mild days in January.

\section{Distribution.}

While the Mollusca were no doubt originally marine animals, the Amphincura, Scaphopoda, and Cephalopoda are the only classes that are still confined to the sea. Some families of Gastropoda and Lamellibranchia are represented by an abundance of

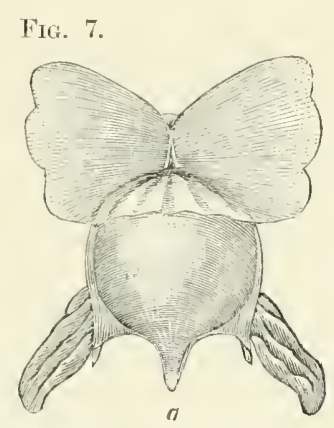

Shell-bearing Pteropod (Carolinit tridentata). Case 96.

$a$. shell and animal; $b$. side view of shell; $c$, dorsal view of shell.

species in fresh water, while the Gastropoda alone have succeeded in adapting themselves to a life on dry land.

In the sea molluses form a large part of the bottom fauna. On a sandy bottom, for example, Lamellibranchs are sometimes the only large animals brought up by the dredge. On rocky coasts in the British Isles the most obvious animals between tidemarks are the Common Limpet, the Dog-Whelk, and the Periwinkle. On tropical shores Lamellibranchs and Gastropods of large size and brilliant colours are frequently conspicuous and abundant. In the ocean Mollusca are known to extend to abyssal depths, even to 2,900 fathoms. The pelagic floating fauna (plankton) of the sea includes certain aberrant Gastropods such as the Sea-Butterflies (Pteropoda) and the Heteropoda, the former sometimes occurring in vast shoals.

On land the Stylommatophora (including the true Snails, Helicilae, and Slugs) are a remarkably numerous group. Land Mollusea have a very wide range, and their habitat includes 
forests, deserts, marshes, and momntains. A species of the Slug Anadenus oceurs at 16,400 foct in the Himalayas, but this reeord is surpassed by a freshwater Snail whieh has been found at 18,000 feet. The most northerly point at which land Mollusea have been obtained is in $72^{\circ} \mathrm{N}$. lat. in South Greenland (Vitrina angelica).

A certain number of Gastropod and Lamcllibranch genera contain exelusively brackish water species. Certain forms of Paludestrina, Auricula, and Scrobicularia are confined to coastal ditches, estuaries, and ereeks, while the estuaries of large tropical rivers contain a special mollusean fama. The distribution of land forms is in general determined by the amount of moisture and to a less degree by the nature of the soil and possibly by temperature. Individual speeies may be very rigidly limited in their distribution by obstacles to dispersal.

The Mollusea are abundantly represented in the fossil state and are found from the Lower Cambrian upwards. The Gastropoda are probably the earliest that can be recognized, but the main classes were differentiated at least as early as the Silurian epoch.

The Mesozoic era was remarkable for the great abundance and varicty of the Cephalopoda (Ammonites, Belemnites, \&e.). The 'Tertiary fauna as a whole is very like that of the present time, and a great number of existing genera originated within the era. Some are, however, mueh older, one of the most remarkable being the Gastropod genus Pleurotomaria, which is recognizable in Silurian roeks and has survived until the present day.

For a more complete aceount of fossil Mollusea the visitor is recommended to consult the Guide to the Fossil Invertebrate Animals.

\section{VARIATION.}

Variation among Mollusca is illustrated by some selected examples exhibited in Wall-ease A and Case 135.

Variation is sometimes direetly dependent on ehanges in the external conditions of life. Thus various Nudibranchs change their colour accorcling to the plants or animals on whieh they feed, Fiona marina, for example, beeoming greyish blue or brown aecording as it feeds on the Coclenterate Velella or the Barnacle Lepas.

Changes in the eomposition of the water may induce marked alteration in the form and shape of the shell in aquatic Mollusea. A deerease in salinity will often bring about a deerease in the thiekness of the shell in Patella, Buccinum, and Littorina. In the relatively fresh water of the Baltic Sea the marine Gastropods Nassa reticulata and Littorina rudis are notably shorter than those in the North Sea, while the proportions of the shell in Cardium edule are modified by fresh water in the Sea of Aral. That excess of salimity may have a similar adverse effect upon the 
shell has been shown in molluses inhabiting lakes and lagoons. C'hanges in temperature may also induce various changes, e.g. in colour and in the shape of the shell. Thus the Slug Amalia gracilis at a constant temperature of $25^{\circ} \mathrm{C}$. is yellowish brown, while it becomes black if the temperature is decreased to $10^{\circ} \mathrm{C}$.

Other factors whieh we can distinguish with less certainty sometimes produce remarkable changes in structure. The shell of a form of Limnaea andersoniana found in ponds in the Shan States has a short spire, the body whorl large and swollen, and the aperture wide. Another form of the same species found in streams has a narrower shell, with the spire longer and the aperture snaller. Similar differences exist between two forms of European Limnaea (L. orata and L. peregra), and it is stated that it is possible to change the shell-form of the one into that of the other by transferring the eggs of $L$. ovata to running water or those of $L$. peregra to still water.

While such variation appears to be the clirect result of changes in environment there are others which cannot be ascribed to this cause; for instance, the diversity of colour-marking seen in certain common Snails (Tachea nemoralis and $T$. hortensis) (Case No. 135).

\section{Economic Importance.}

IIollusca have been used as food by man at least since the Palaeolithic period, and in every region of the world. Although the oyster is, and has been sinee Roman times, the most highly esteemed, several other less valuable species are very largely consumed in this country. For example, in 1922, the following quantities of edible molluses were delivered at Billingsgate Market, London: oysters, 1,207 tons; mussels, 1,888 tons; periwinkles, 3,245 tons; whelks, 889 tons; cockles, 88 tons. (Data kindly supplied by the Fishery Department, Fishmongers' Company.)

The edible Snail is sufficiently important in France to make its cultivation a regular industry. Mollusea may also be of importance to man as the food of edible fishes; for example, Lamellibranchs form 80 per cent. of the food of the Plaice.

The most valuable commercial products furnished by Mollusea are pearls, which are obtained from the Pearl Oyster (1/argaritifera) and a few other Lamellibranchs. An account of the formation of pearls will be found on p. 39 .

Mother-of-pearl derived from the shells of several genera of marine and freshwater Lamellibranehs is an important article of commerce for button-making and other purposes. The cultivation of many species of River Mussels (Unionidae) in the United States for the production of pearl shell is an industry which in recent years has assumed large proportions. 
The purple elye obtained in ancient times from several species of marine Gastropods is well known, and various savage tribes at the present day employ dyes obtained from these animals.

There are many liollusea which are directly or indirectly harmful to man. Some of these are illustrated in the two exhibits of 'Marine Boring Animals' and 'Biology of Waterworks' in the Central Hall and are described in the Guide-books to these ('xhibits.

The importance of slugs and snails to gardeners and other cultivators is well known.

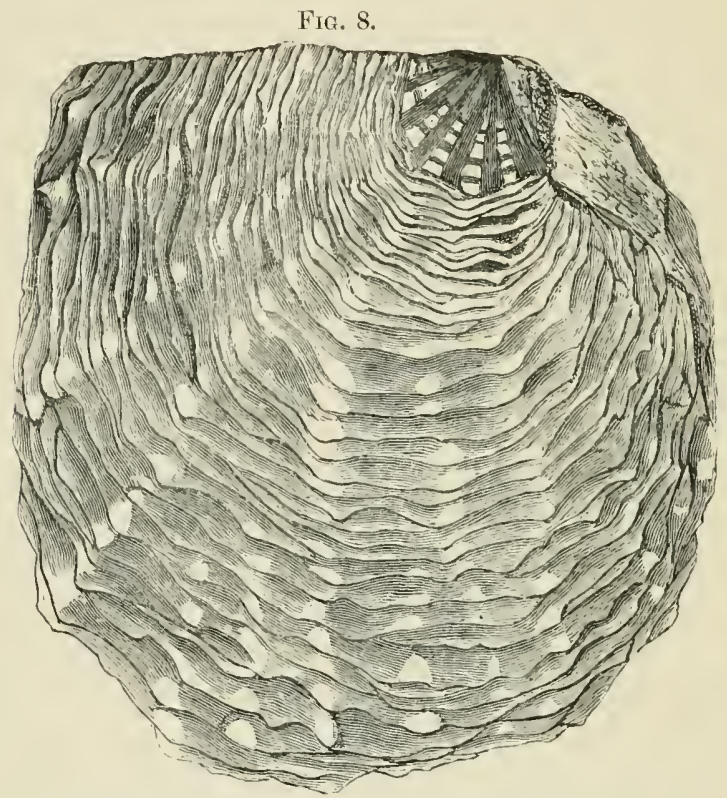

Pearl Oyster (Margaritiferu margaritifera). (ase 147.

Some molluses play an important part in the transmission of diseases. Certain freshwater Snails act as the intermediate hosts of Trematode parasites which infect man or domestic animals. Fasciola hepatica, the liver-fluke which eauses liver-rot of shecp in Europe, passes part of its life in the body of the Pond-Snail Limnaea truncatula; and species of Schistosoma, Trematodes that cause serious disease in man in tropical and sub-tropical countries, similarly undergo part of their development in freshwater molluses (Hypsobia nosophora in Japan and Isidora contorta and Planorbis boissyi in Egypt). 


\section{C'lasis I. AMPHINEURA. \\ (Cises 1 to 3.$)$}

These Mollusea are elongate and bilaterally symmetrical, with the head and anus at opposite ends of the body. They are all marine animals, and some of them are found at great depths. Spicules are present in the mantle. The Amphineura are divided into two orders, the Polyplacophora and the Aplacophora.

'The Polyplacophora include the 'Coat-of-mail' Shells (Chitonidae). They are characterized by the possession of a series of

\section{FIf. 9.}
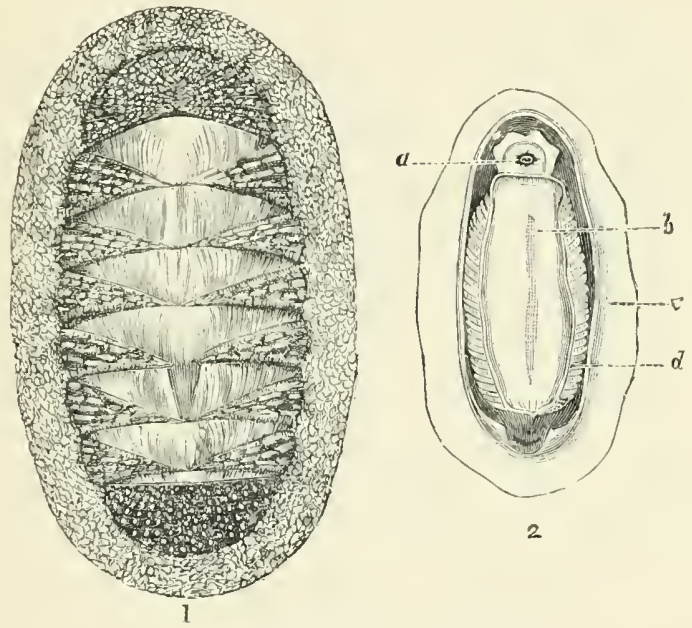

1. Chiton squamosus (upper surface).

Coat-of-mail shells, or Chitons.

2. Chiton elegans (lower surface) : $a$. mouth ; $b$. foot; $c$. mantle; $d$. gills

eight plate-like shells on the back, typically well developed and overlapping (e.g. Chiton) but in some genera (e.g. Cryptoplax, schizochiton) reduced and well separated. In many forms the shells are covered over by the mantle, as in the giant ('ryptochiton stelleri of the North Pacific. The shell is traversed by a number of fine branching eanals in which are lodged peeuliar sense-organs known as 'shell eyes'; these may have a retina and lens. The upper surface of the mantle may be smooth, granular, or armed with spicules. Between the foot and the mantle is a row of gills which may be nearly continuous round the body. The heart is dorsal in position and is very elongate.

Chitons are found in all parts of the world. They live chiefly on rocks and stones in pools near low tide-mark, but a few have 
been obtained from deptlis of over 2,000 fathoms. About 600 living species are known, including more than a dozen from British coasts.

These animals, like woollice, have the power of rolling themselves into a ball. In some of them the eggs are incubated in the furrow between the gill and the foot; in Callistochiton viviparus derelopment is direct, and takes place in the oviduct.

The Aplacophora (Case 3) are worm-like and devoid of shelis ; the mantle usually covers the body completely, a median ventral furrow remaining uncovered in Neomenia and its nearest allies. The foot is very much reduced in size or is absent altogether. The gills are contained in a special eavity at the posterior end of the body. These animals live on oozy bottoms, sometimes at very great depths. Neomenia and allied genera are usually found upon corals and Hydroids. A few species occur in British Seas.

FIG. 10.

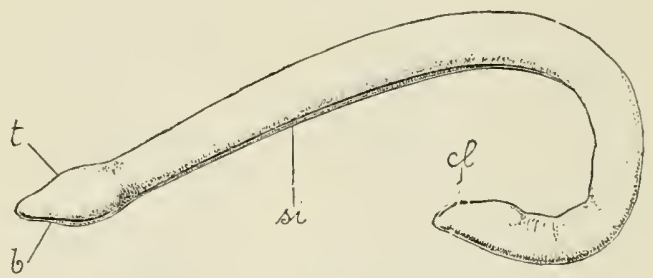

Proncombenia gorlacheri, left side view.

b. mouth ; $c l$. cloaca ; si. foot groove; t. head.

From Lankester's T'reatise on Zoology (by permission of Messis. A. \& C. Blaek).

\section{Class II. GASTROPODA. \\ (Cases 3 to 136.)}

This class contains some of the most familiar molluses, such as the Limpet, the Whelk, the Snail, and the Slug. Most Gastropods have a spirally coiled shell and a well-differentiated head region, and their internal organs are asymmetrical. During the development of the Gastropoda the original symmetry of the larva is affected by two processes known as "ventral flexure" and 'torsion'. As a result of these the anus, which was originally posterior, becomes anterior and ultimately reaches a position above the mouth, the visceral commissure of the nervous system is twisted into a figure of eight, and certain organs of the original left side tend to atrophy and may disappear. There are many Gastropods in which the visceral commissure is untwisted, and some of these are symmetrical and liave the anus in its original posterior position ; but they have only one auricle of the heart, and one kidney, and it seems elear that their apparently primitive 
features are really seeondary. The Gastropoda are divided into two sub-classes, the streptoneura, in which twisting of the visceral commissure is well marked, and the Euthynenta, in which ministing has taken place. In the Streptoneura the nervous ganglia are relatively little eoneentrated, whereas in the Euthyneura they are, as a rule, much concentrated in the head region. A structure present in most Streptoneura, but in only a few Euthyneura, is the opereulum, a hard plate borne on the upper surface of the foot, serving to close the aperture of the shell when the animal is withdrawn. In the majority of the Streptoneura the sexes are separate, but all Euthyneura are hermaphrodite.

Fig. 11.
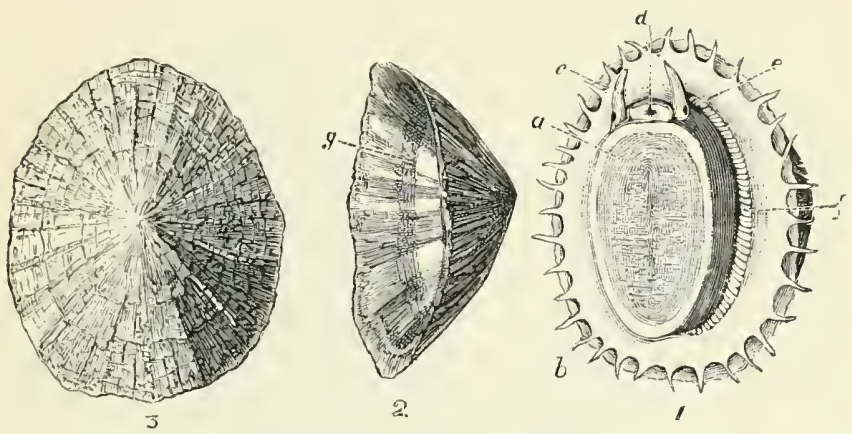

The Common Rock-Limpet (Patelle vulyata). British.

1. Animal: $a$. foot; $b$. fringed mantle; $c$. tentacles; $d$. mouth; $e$. eyes; $f$. gills.

2. Side view of shell, showing the impression or sar of the attachmentinuscle, $g$.

3. Uprer surface of the shell.

\section{Sub-class I. STREPTONEURA.}

\section{Order 1. ASPIDOBRANCHIA.}

(Cases 3 to 20.)

This order includes Gastropods with paired auricles of the heart, paired kidneys, and oceasionally paired gills, and with the gillfilaments set on opposite sides of a main axis. The first sub-order, the Docoglossa, is so called because the teeth of the radula have the shape of beams. It includes the Limpets (Acmaeidae and Patellidae), in which the shell is not spirally coiled.

'The Acmaeidae are called 'false Limpets', because, although their shells are similar to those of the true Limpets, they have a single true gill, whilst the Patellidae have false gills greatly developed as outgrowths of the mantle all round the sides of the 
foot. Both the true and false Limpets are littoral and are found on rocks between tide-marks. They have the power of excavating the surface to which they attach themselves, the secretions of the disk-like foot dissolving away the rock to form a shallow pit, to which the animal is known to return with great constancy. The largest known Limpet (Palella (Ancistromesus) mexicana, Case 7) inhabits the west coast of Central America, its shell having sometimes a length of 12 inches. The Limpets are vegetable feeders and live on seaweeds of various kinds, which they rasp with their radulae. That of the Common English Limpet (P'vulgala, Fig. 12)

Fis. 12.

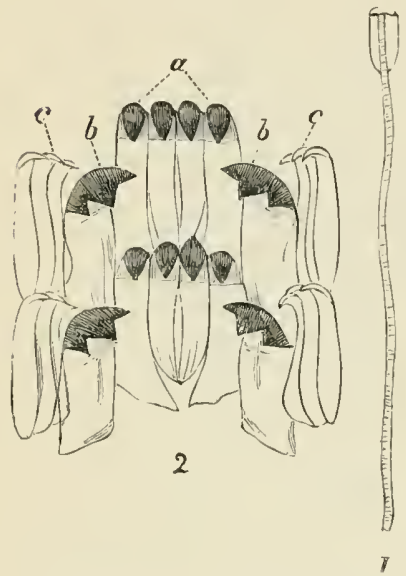

1. Radula of the Common British Rock-Limpet (Patella vulgata), natural size.

2. Two transverse series of teeth: $a$. median teeth; $b$. laterals; c. uncini or marginals.
Fis. 13.

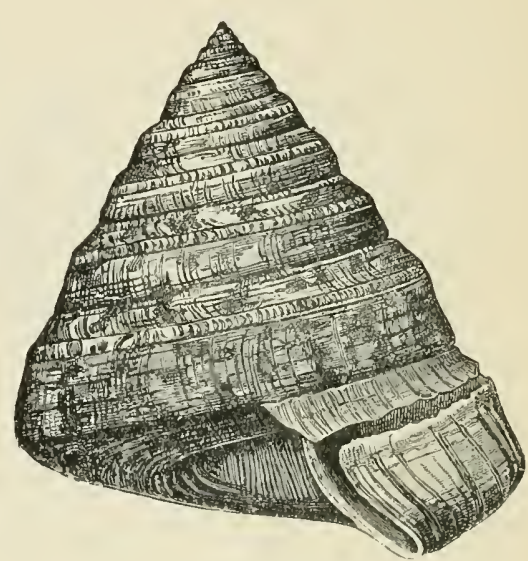

Pleurotomaria adansoniana. Case ?. $\frac{1}{3}$ natural size.

From The Cambridge Naturnl IIistory, by permission of Messrs. Maemillan \& C'o.

is longer than the shell itself, and is armed with as many as 1,920 hooked teeth in 160 rows of twelve each. The Limpet is commonly used for bait in the sea-fishing off the Scottish coast. Some Limpets, such as $P$. compressa, $P$. mytilina, \&c., are found on the stems of floating seaweeds, and have the shells usually thinner and smoother than the Rock-Limpets, which have to resist the fury of the breaking waves.

The second sub-order, the Rhipidoglossa, is so called because the teeth of the radula are arranged like a fan. It includes the remaining Aspidobranchia.

The 'Keyhole Limpets' and 'Slit Limpets' (Fissurellidae) resemble in external shape ordinary Limpets, but have the shell 
perforated at or near the apex, or mone or less stit at the fromt margin. "The hole or slit gives passage to a tubular oritice of the: mantle, through which exereta and water used for respiration escape. 'The largest species are from California and South America.

'The Pleurotomaridae ar'extremely rare in reent times, only six species being known, whereas over a thousand fossil forms lave been cleseribed.

'The 'Ear-shells' or 'Ormers' (Haliotidae) are found adhering to rocks in most parts of the world, with the exception of South America. Like the Limpets they hold on to the rocks with great tenacity. The shells are lined with mother-of-pearl, and many exhibit splendid colons and seulpture. The shell of Haliotis is piereed by a series of holes parallel with the left margin ; throngh these the animal protrudes slender tentacles. Haliotis tuberculata

FIt. 14 .
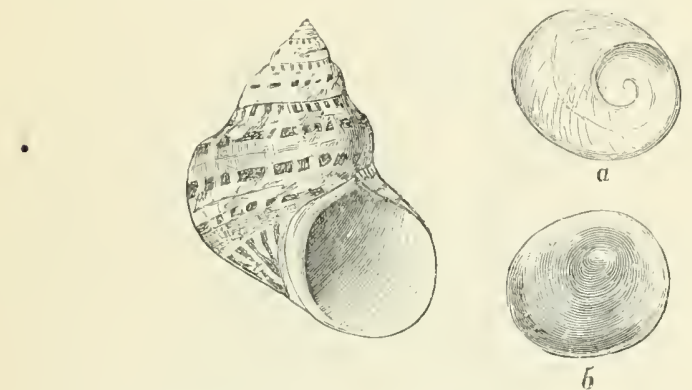

Top-shell (Turbo petholatus). (From the Indo-Pacifie Ocean.) a. Inner surface of operculum; $b$. exterior of ditto.

is common on rocks and stones at low water in the Channel Islands and the North of France, where it is frequently eaten; other species in New Zealand, China, Japan, West Africa, and elsewhere, constitute a common article of diet. Haliotis shells are largely used in the manufacture of pearl ornaments, and in all kinds of inlaid work.

The Trochidae and Turbinidae are two extensive families mainly distinguished by the operculum, which is horny in the former, and shelly in the latter. The shells of these molluses are pearly within, and are generally brightly coloured and highly ornamented. Several very pretty species are found on our own shores.

Of the Neritidae the species of Nerita are mostly found in tropical countries, and like the Periwinkles have very strong shells to resist the force of the breaking waves. Neritina ineludes both marine and freshwater species, which have less solid shells. The shell of Septaria is shaped very much like those of Limpets, except that the apox is at one end instead of central. 


\section{Order :. PECTINIBRANCHIA.}

(C'ases 22) to 94.)

This order includes Streptoncurous Gastropods with only one auriele. one kidney, and one gill. The gill has lost the filaments of one side, by which it is attached to the mantle. In the first sub-order, the Taenioglossa, the radula has usually several teeth in each row. This sub-order includes a large number of families (Tieiparidae to Carinariirlae).

The 'River-Snails' (Tiviparidae) are rather sluggish, and are found at the bottom of ponds and rivers feeding on decaying animal and regetable matter. The eommon British species is Tivipara vivipara, the female of which rears the young in a brood pouch at the end of the oviduct.

FIG. 15.

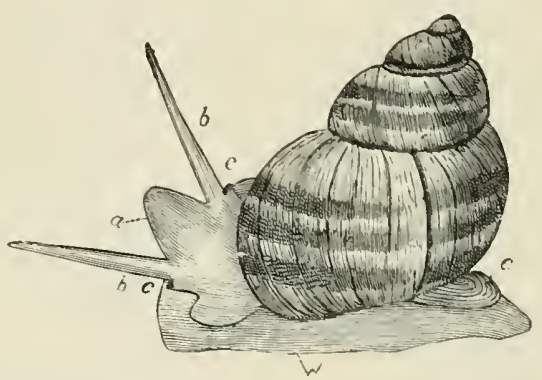

The Common British River-Snail (Vivipara vivipara). $a$. head : $b$. tentacles; $e$. eyes; $d$. foot ; $e$. operculum.

The Cyclophoridae and Cyclostomatidae are Land-Snails with the mantle-cavity converted into a lung. Some have remarkable devices for admitting air to the lung when the operculum is closed, c.g. the siphonal notch and groove in Catanlus (Case 24).

The 'Apple-Snails' (Ampullariidae) live in the rivers and marshes of tropieal regions, and, although represented by a large number of species, exhibit comparatively slight variation in form and colour. In this family a gill and a lung occur together, and the latter can be used for respiration under water by means of a long siphon which ean be protruded upwards into the air.

The 'Periwinkles' (Littorinidae) are found almost on every lnown shore; they feed upon all kinds of marine vegetation. Some species are met with at low-water mark, others on rocks almost beyond the reach of the sea, and some have been discovered inland nearly half a mile away from the shore.

The family of Calyptraeidae includes the 'Slipper-Limpets' 
(Crepidula) and the 'Cup-and-sancer Limpets' (Crucibulum). 'They rarely erawl about, but remain attached to rocks, stones, or other shells, sometimes forming a shelly plate under the foot by which they beeome fixed to the spot where they have taken up their abode. The Ameriean Crepidula fornicata has established

Fig. 16.

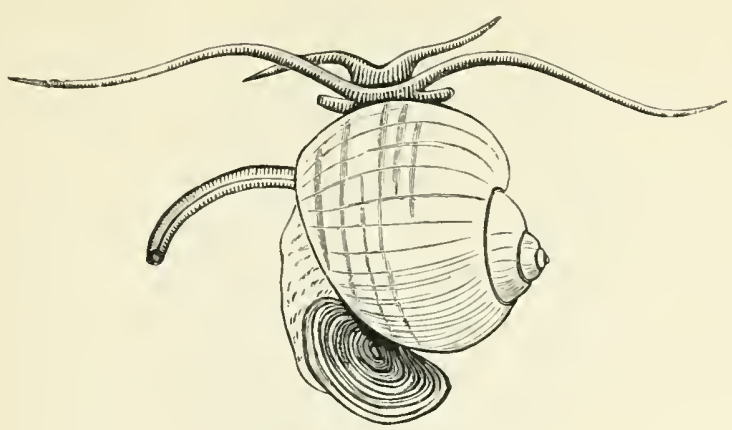

Ampullaria canaliculata.

FIG. 17.

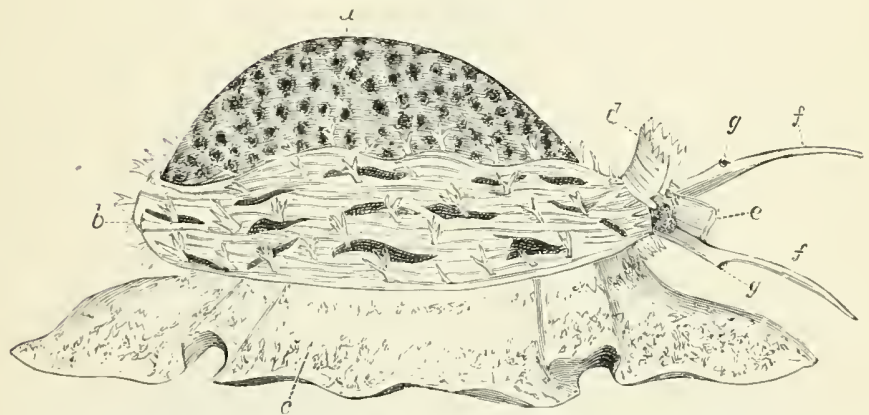

The Tiger Cowry (Cypruen tigris). (From the Indo-Pacifie Ocean.) $a$. the shell; $b$. the mantle; $c$. foot; $d$. siphon; $e$. proboscis; $f$. tentacles ; g. eyes.

itself on the coasts of England to the great disturbance of Oyster culture. The Slipper-Limpet multiplies very rapidly and enerusts the Oyster-beds, intereepting the normal food of the Oysters. These animals settle down in elusters one on top of another (Case 31). In the individuals eomposing sueh strings there is a change of sex, the oldest (at the bottom) being females, the intermediate ones hermaphrodite, and the youngest (at the top) males. 
The 'Cowries' (Cypracidue) are remarkable for their varied markings and splendid polish, which is produeed and preserved by two flaps of the mantle, one on each side, which fold over the

litu 18.
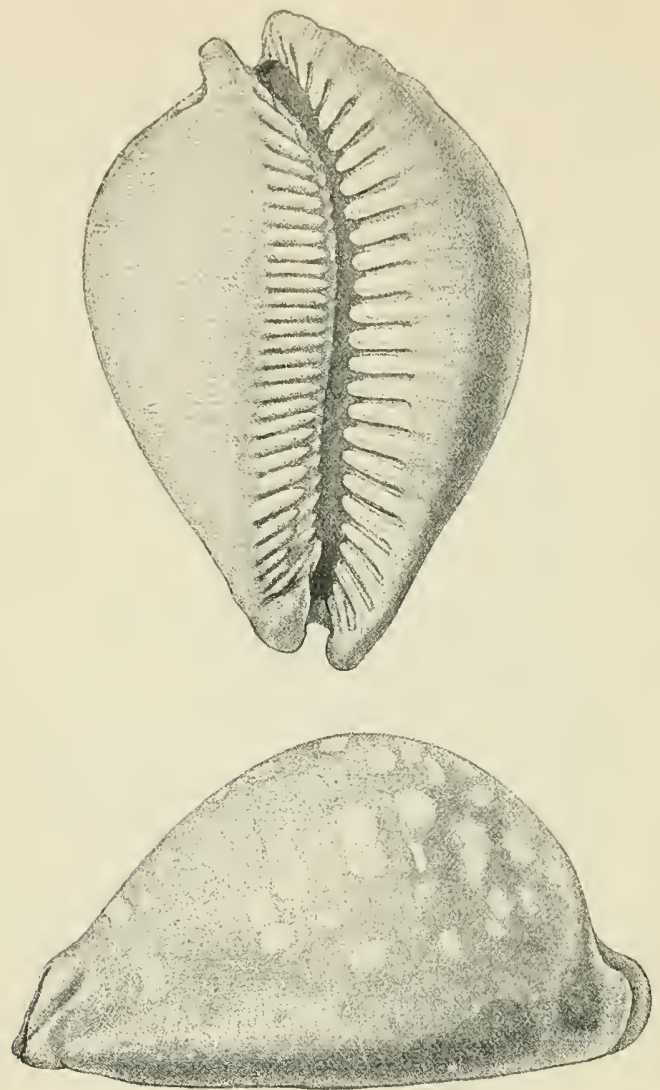

Cypreatencodon. C'ase 32.

shell, a line down the centre of which usually marks where the flaps meet. The animals are even more brilliantly eoloured than the shells. Cowries, as is well known, are sold as ornaments; and a small yellow species, 'the Mloney-Cowry' (C. moneta), which is very common in the Inclian and Pacific Oceans, passes current as coin among the negro tribes of certain parts of Afriea. 
'The 'Orange-Cowry' (Cypraea aurantinm) is worn by chicfs in the friendly Islands, and is consictered the highest order of dignity. Only one small species, Trivia europaea, is found on the British coasts.

Of the Ornlidae, the niost curious is the "IVeaver's-shuttle" (Badius rolva), in which the shell is peculiarly beaked at both ends. It is found living on Gorgonian corals (Gorgoniidae), and some of the smaller species exhibit clifferences of coloration, resembling: the tints of the corals upon which they are found.

The Lamellariidae (Case 37) live on or embedded in 'Tunicates, in which they deposit their eggs ; the shell is more or less completely covered over by the mantle.

The "Violet Snails' (Ianthinidae) are found floating about in every ocean, exeepting in cold regions, with the spire of the shell downwards. They feed upon Jellyfish, and secrete a gelatinous raft, filled with air-bubbles, to the underside of which the eggs are attached.

The Melaniidae are freshwater snails which abound in most tropical and subtropical countries. They are mostly of dark colours, and are found in muddy places.

The Cerithiidae are chiefly marine forms, some, however, entering brackish water. About five hundred fossil species have been described, some of them gigantic in comparison with any now living.

The three families Pyramidellidae, Eulimidae, and Entochonchidae are known as the Aglossa, as they have no radula. Most of the Eulimidae and all the Entoconchidae are parasitic on Echinoderms, and some are very degenerate in structure.

The 'Worm-shells' (Vermetidae) are a very peculiar family. Their shells can scarcely be distinguished from the shelly tubes which are formed by certain species of marine worms (e.g. Serpula, \&c.). They are free and spiral in early life, but afterwards become partly ' unwound' and generally attached to rocks, stones, \&c. Sometimes they form large encrusting masses.

The 'Screw-shells' (Turritellidae) have elongate, tapering shells. Turritella communis is found on the British coasts.

The Xenophoridae have the singular habit of cementing to the exterior of their shell stones, pieces of coral, and fragments of other shells; hence they have been called 'Carrier-shells', and, according to the kind of material chosen, have been named 'Conchologists' and 'Mineralogists'. Beyond aeting as a disguise, and consequently as a protection, there does not appear to be any special utility in thus adding to the weight of their own shells. The animals do not glide like other molluses, but seramble along.

The 'Wing-shells' (Strombidae) do not crawl like most other Gastropods, but progress by a sort of jerking movement or by 
vigorous leaps. They aet as seavengers, feeding on decomposing animal matter.

Strombus gigas, or' 'the Fountain-shell', occurs in great numbers in the West Indies, and is a very heary solid shell. At one time it was used for cameo-earving and was also employed in the manufacture of porcelain, as many as 300,000 shells having been imported into Liverpool in one year for that purpose.

The Scorpion-shells (Plerocera), or 'Spicler-elaws', as they are sometimes called, possess singular claw-like projections, which are developed on the outer lip of the shells.

The 'Trumpet-shells' (Cymaliidae) have strengthening ribs at intervals, like the Murices; the largest species, Cymatium variegatum, is used by South Sea Islanders as a horn or trumpet. A hole is made in the upper part of the spire to blow through, and the sound produced ean be modulated or varied by inserting the hand in the aperture or mouth of the shell.

FIG. 19.

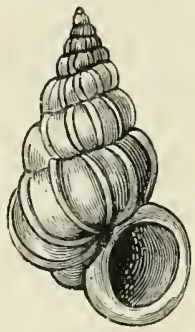

Scala sculuris. Case 44 .

The 'Helmet-shells ' (Cassididae) were used for cameo-earving ; they consist of clifferent layers, so that the ground colour of the earving is of a different tint from the subjeet engraved.

The 'Tun-shells' (Doliidae or Tonnidae) are remarkable for the globoseness of the shells, whieh are covered with very regular ribs.

The Atlantidae, Plerolracheidae, and Carinariidae, at various times reeognized as forming a distinct sub-elass or an order of Gastropoda, under the name of Heteropoda, are now regarded as speeialized Taenioglossa organized for swimming in the open sea, the foot being compressed to form a sort of fin. The Atlantas are found in great numbers in warm and temperate latitudes, and are provided with a thin, flat, spiral shell. The shell of Carinaria is one of the most beautiful struetures of any molluse ; the animal is large, semi-transparent, and elongate. Speeies of this genus are found in the Mediterranean and warmer parts of the Atlantic and Indian Oceans. They feed on Jellyfish of various kinds, and probably on other soft-bodied animals. 
The remaining families constitute the seeond sub-order of the Pectinibranchia - the Stenoglossa. In these the mouth is at the end of a protractile proboscis, and the radula has only two or three teeth in each row ; these are, however, strong and often heavily scrrated.

The Fasciolariidae contain two of the largest living Gastropods: Vegalatractus aruenus, from North and West Australia, and Fasciolaric yigantea, which is found off the eoast of Sonth Carolina, and attains at times a length of 2 feet.

The Mitridae are great favourites with shell-eollectors on aecount of their beautiful colours and varied sculpture. Shells of this group, like the Fasciolariidae, are distinguished by a few plaits or folds on the inner side of the aperture (the columella). They are almost exclusively found in tropical or sub-tropical

FIG. 20.

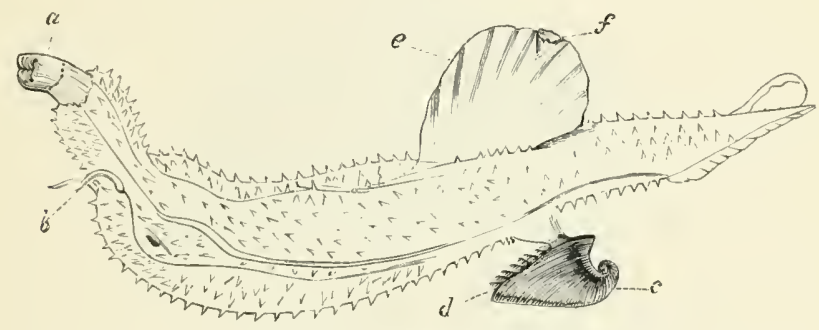

Heteropod (Curinaria lamarcki).

(.) proboscis ; $b$. tentacles; $c$. shell ; $d$. gill ; $e$. foot ; $f$. sucker.

regions, the majority being met with either at low-water mark or in comparatively shallow water.

The Buccinidae also contain a very large and varied assemblage of forms. Among them may be mentioned the Whelks (Buccinum).

The family of II uricidae, or 'Rock-shells', contains many very handsome and peculiar forms. They are all carnivorous, feeding chiefly on other Mollusea, boring through the shells of Lamellibranchia and slowly devouring the inhabitants piecemeal. The shells of II urex produce at intervals ribs, which in some species are ornamented with long spines or foliations. From eertain species of Murex (M. brandaris, \&e.) found in the Mediterranean was manufactured the celebrated Tyrian dye.

The Purpuridae are fonnd between tide-marks all over the world. The Coralliophilidae are sedentary, living on or in corals. In Magilus, which in its early spirally coiled stage settles down on a coral (Mecondrina), the aperture of the shell grows into an elongate tube, in order to keep pace with the growth of the eoral. 
'The Folulidae are much sought after by shell-collectors ; some, of them attain to a very large size. They are found chiefly in the warmer parts of the Atlantic and Tndo-Pacific Oceans, and oceur in the greatest varicty on the coasts of Australia.

The Olividae are common in most tropieal seas; their shells are remarliable for their beantiful polish and various patterns of colouring. 'They burrow in sand in quest of bivalves for food, and some species are said to have the power of swimming by expanding the lobes of the foot.

The Harpirlae form a small, woll-marked group. The animals as well as the shells are brightly coloured. They have the remarkable power of easting off a portion of the foot when disturbed. The species are known from the Indo-Pacific Ocean, the west coast of Central America, and West Africa.

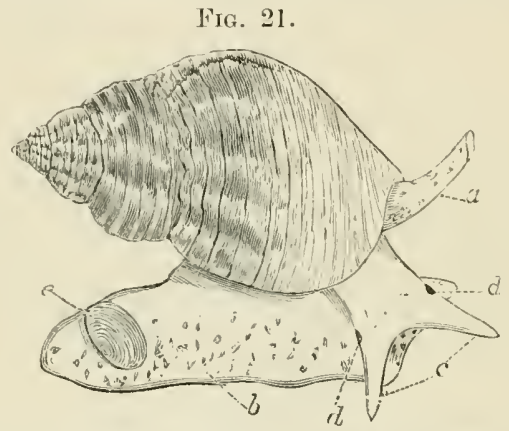

The Common Whelk (Buccinum undatum).

$a$. siphon; $b$. foot; $c$. tentacles; $d$. eyes ; $c$. operculum.

The next family, the Pleurotomidae or Turridae, consists of very numerous species, over a thousand living forms having been diseovered, and almost as many fossil species from Cretaceous and Tertiary strata. The typical forms are characterized by a slit in the outer side (lip) of the aperture. Species of Pleurotoma are found in every sea, although most abundant in the tropies.

The 'Auger-shells' (Terebridae) have a great diversity of external omamentation. They are all elongate shells, with a deep notch at the base of the aperture.

The Conidae, or Cones, are found in all tropical seas. This family, of which between 400 and 500 distinct kinds are known, is a great favourite with collectors on account of the brilliant colours and various patterns of the shells. They are all carnivorous, and live usually in shallow water among rocks and coral-reefs. They possess a poison-gland, and several species are recorded as having inflicted poisonous bites, often with serious results. 


\section{Sub-class 2. EUTHYNEURA.}

The Gastropods belonging to this sub-class, with few exceptions, have the visceral nerve-loop uncrossed. All the Euthynema are hermaphrodite, and their radula is generally composed of numcrous similar denticles on each side of a median tooth. Seareely any are provided with an operculum in the adult state. The Enthyneura may be divided into two orders, Opisthobranchia and Pulmonala.

\section{Order 1. OPISTHOBRANCHIA.}

All the molluses of this order are marine, some (Tectibranchia) breathing by means of the ordinary Gastropod gill (ctenidium), which is generally behind the heart, whereas others ( $\mathrm{Tudi}$ -

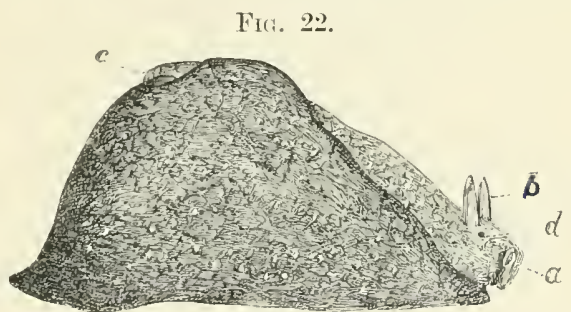

Sea-Hare (Tethys (Aplysin) punctata). British.

a. labial ientaeles: $b$. upper tentacles or rhinophores; $c$. siphonal fold of the mantle near the shell; $d$. eye.

branchia) have lost the true gill and have developed a different type of respiratory organ.

'The Teclibranchia include the 'Bubble-shells' (Bullidae), the 'Sea-Hares' (A plysiidae), the 'Umbrella-shells' (Umbraculidae), the 'Pteropods', formerly considered a clistinct class, and some others. In the more primitive types (e.g. Actueon, Scaphander, Bulla) the shell is well developed and mitwisting of the visceral nerve loop is incomplete; in others the shell may be reduced or absent.

The Pteropods, sometimes called Sea-Butterflies, comprise two groups, Pterota and Eupteropoda, ${ }^{1}$ which are organized for swimming freely in the ocean. They have a pair of fins developed from the sides of the foot. The Eirpteropoda are provided with small glassy shells; the Pterota are naked. Pteropods may constitute an important part of the food of the Baleen Whales.

1 The union of these two groups under a single name, though convenient for several reasons, is not justifiable systematieally. The Eupteropoda are more correctly classified with the Bulla-like forms and the Pterota with Aplysin and its allies. 
'They exist in comtless millions in some parts of the ocean, discoloming the water for miles. In certain regions the bottom of the occan, in depths between 1,000 and 2,000 fathoms, is covered by a thick ooze formed from their shells.

The Sea-Hares, so ealled on account of a slight resemblance to a cronching hare, are found in most parts of the world. At the hinder part of the back two flaps of the mantle partly conceal a thin homy shell which serves as a protection to the gills and vital organs beneath. When molested, these animals clischarge a large quantity of a purple fluid, discolouring the surrounding water for a clistance of more than a yard.

The remarkable shell of Umbraculum is shaped very like a Chinese umbrella.

The Nudibranchs or Naked-gilled Molluscs comprise some of the most beautiful and strange forms. They are unprovided with Fig. 23.

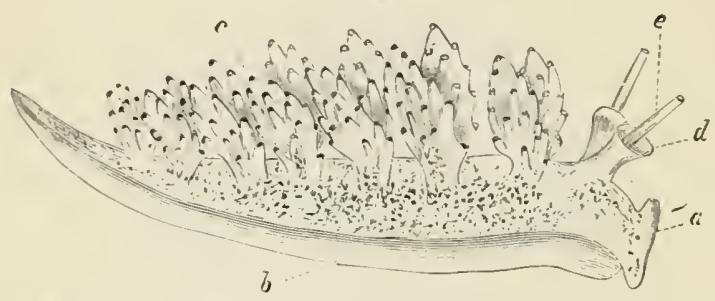

Naked-gilled Mollusc, or Nudibranch (Doto coronata).

$a$. head : $b$. foot; $c$. dorsal papillac: $d$. tentacle-sheath; $e$. tentacle.

shells except in the earliest stages of their existence, when they have a minute coiled (and often nautiloid) shell, furnished with an operculum, both of which are subsequently cast off. Some of them bear on the back a series of appendages, often fantastically shaped. Unfortumately the colours of these beautiful creatures cannot be preserved after death, and therefore a small series of glass models is exhibited, which will give some idea of their great variety in form and colouring. They are found in most parts of the world, chicfly in shallow water, but a few species live upon floating seaweed in the open sea. Over a hundred species exist on the British coast. the majority of which are, however. very small. They are chiefly carnirorous, feeding on other molluses, Sea-Anemones, \&c.

\section{Order 2. PULMONATA.}

$$
\text { (Cases } 97 \text { to 135.) }
$$

The Pulmonata are Euthyneura in which the mantle-cavity is converted into a hing. There is no true gill, but in certain aquatic 
forms gill-like structures may be developed in the mantle-eavity. Iost Pulmonata are provided with shells, but, with the exception of the Amphibolidae, the adults never possess an opereulum. The majority are terrestrial, but some are aquatic and there are a few marine forms. They aro divisible into two sub-orders, Basommatophora and Stylommatophora, eharaeterized by the difference in the position of the eyes. The Basommatophora, including the Auriculidae, Amphibolidae, Siphonariidae, and Limnacidae, have a single pair of tentacles, at the base of which the eyes are situated. The Stylommatophore (Land-Snails, Slugs, \&e.) are
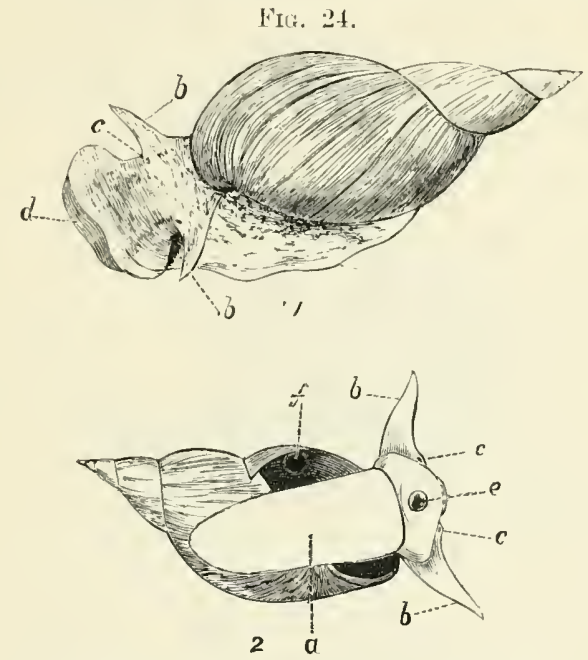

British Pond-Snail (Limbnaea stagnalis).

1. Upper view : $a$. foot; $b$. tentacles ; $c$. eye; $d$. muzzle.

2. Lower view : letters $a . b . c$. as above; $c$. mouth $; f$. respiratory orifice.

provided, save in a few eases, with two pairs of retractile tentacles, with the eyes at the summit of the hinder pair. Over 10,000 species of Pulmonata are known.

\section{Sub-order 1. Basommatophora.}

The Auriculidae chicfly inhabit salt or brackish water. The largest forms are tropical and found at the mouths of rivers, among the roots and stems of mangrore-trees, or in damp wood near the sea.

The 'Limpet-Snails' (Siphonariidae) look very like true Limpets, but their shells are distinguished by a slight bulging on one side, eaused by a groove on the inside which lodges a respira- 
tory siphon. 'They are marine, and are found on rocks between tide-marlis, chicfly in tropical countries.

'The Limnacidae are found only in fresh water. Ilost of them occasionally rise to the surface to breathe, where they glide along foot mpermost, at times suspending themselves by a glutinous thread, after the fashion of a spider. Limmaca stagnalis is the eommon Pond-snail of Britain.

'The freslowater Limpets (Ancylidue) live attached to stones and leaves of plants. Like the Limnaeidae they feed on freshwater algae, confervae, and decayed vegetable matter.

\section{Sub-order 2. Stylommatophora.}

With the exception of the cosmopolitan marine family Onchididae these Pulmonates are terrestrial.

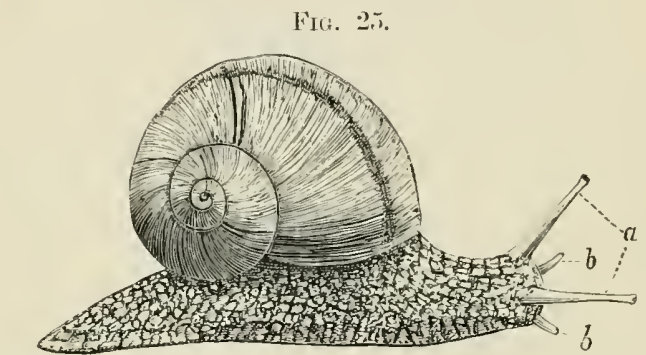

British Land-Snail (Helix pomatict).

$a$ eye-bearing tentacles; $b$. lower or smaller tentacles.

True Snails (Helicidae, Bulimulidae, Stenogyridae, \&e.) are nearly all protected by a spiral shell. They are almost exclusively vegetable feeders, subsisting chiefly on leaves. Many of the species are beautiful objects on aceount of the brilliancy of their coloration, and some are remarkable for the variation they exhibit in this respect. Sjecies of Ilelicidae are found in nearly every part of the world and in all situations, from sca-level to an altitude of 12,000 feet. They are fond of moisture, and in hot and dry weather retire within their shells, remaining torpid until the return of dew and rain. Helix pomatia (Case 119) is commonly eaten in Austria, France, and Belgium.

The eggs of Land-snails vary in texture and size; they are ustually white, but in some instances yellow and pale green. Those of some of the large South-American forms are as hard as that of a hen, and more than an inch in length (Case E).

Slugs (Case 106) are anatomically very like Snails, but possess no external shcll; most of them, however, have a small internal shelly plate, or a few calcarcous granules hidden beneath the 
skin of the back. Some have a large slime-pore at the end of the foot, and others are slightly phosphoreseent. Like the Snails, they are fond of damp localities, and at times become great pests owing to the damage they do to field and garden crops of all linds. T'estacella, which is found, in this eountry, differs from the Slugs in having a small external shell at the posterior end of the body. It is not slimy, and lives underground, feeding upon earthworms.

\section{Class III. SCAPHOPODA. \\ (Case 136.)}

This class consists of but two families-the Dentaliidae and siphonopodidae. These are marine molluses with an elongate

FIG. 26 .

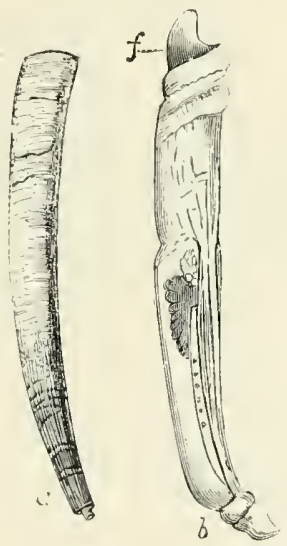

British Tootl-shell. (Dentalium tarentinumb.)

a. the shell; $b$. the animal, removed from its shell; $f$. the foot.

body and tubular shell. The edges of the mantle are united under the foot, forming a tube which, like the shell, is open at both ends. The head bears two lobes which earry numerous filaments; these are sensory and prehensile in function. The foot is capable of eonsiclerable extension and the animal digs itself into the sand with it.

The shell is shaped rather like an elephant's tusk and its larger orifice is at the anterior or head end. The smaller posterior orifice is usually kept out of the sand or mud when the animal is burrowing. Scaphopods are found in all seas, there being seventeen British species. They are found at all depths down to 2,500 fathoms. Dentalium and Cadulus are the most characteristic genera (Case 136). 


\section{Class IT. LAMELLIBRANCHIA.}

\section{(Cases 137 to 204.)}

The Lamellibranchs, or Bivalves, include the Oysters, Cockles, Mussels, \&c. They have no jaws and no radula, and the head and its associated sense-organs are little developed. The body is enclosed between two deep lobes of the mantle which secrete a bivalve shell, the two halves of which are connected by a horny elastic structure, the ligament, and, in addition, are usually articulated together by a series of interlocking 'teeth'. The closing of the valves is effected by a pair of adductor muscles, sometimes reduced to one. When the museles relax, the valves

Fig. 27.
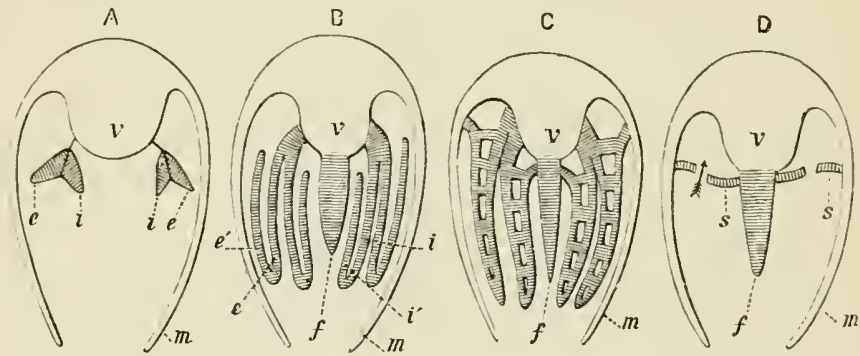

A. Protobranchia ; B. Filibranehia ; C. Eulamellibranchia : D. Septibranchia. m. mantle; $v$. body ; $f$. foot; $e$. outer gill-lamella; $i$. inner gill-lamella : $e^{\prime}$. reflected portion of outer lamella; $i$. reflected portion of inner lamella ; s. gill modified to form a septum.

From The Cambridye Natural History (by permission of Messrs. Macmillan \& Co.).

gape as a result of the elasticity of the ligament. In many Lamellibranchs a special gland in the foot secretes the byssus, a bundle of hard threads that serve to fix the animal down on the bottom. The Lamellibranchia are all aquatic and most of them are marine. They usually burrow in sand or mud, or may be permanently fixed; some (Teredo, Pholas, \&c.) excavate burrows in wood or stone. A few erawl about (e.g. Cyclas) or progress by short leaps (e. g. Tellina) or swim by abruptly opening and closing the valves of the shell (e.g. Lima, Pecten). They do not seek their food, but live on microseopic organisms and organic débris, which are swept towards the mouth by the cilia on the gills.

The Lamellibranchs are very uniform in structure, and this makes them very difficult to elassify; the most satisfactory system is based on the modifications of the gills, which are suspended between the body and the mantle-lobe, one on each 
side. Each gill consists of an axis that is partly attached and of two series of filaments. In the most primitive forms (Irotobranchict) the series of filaments are divergent, but in the majority (Filibranchia, Eulamellibranchia) they are nearly parallel, with each individual filament bent into a proximal (descending) and a distal (ascending) portion. Further complication results from the

Fra. 28 .

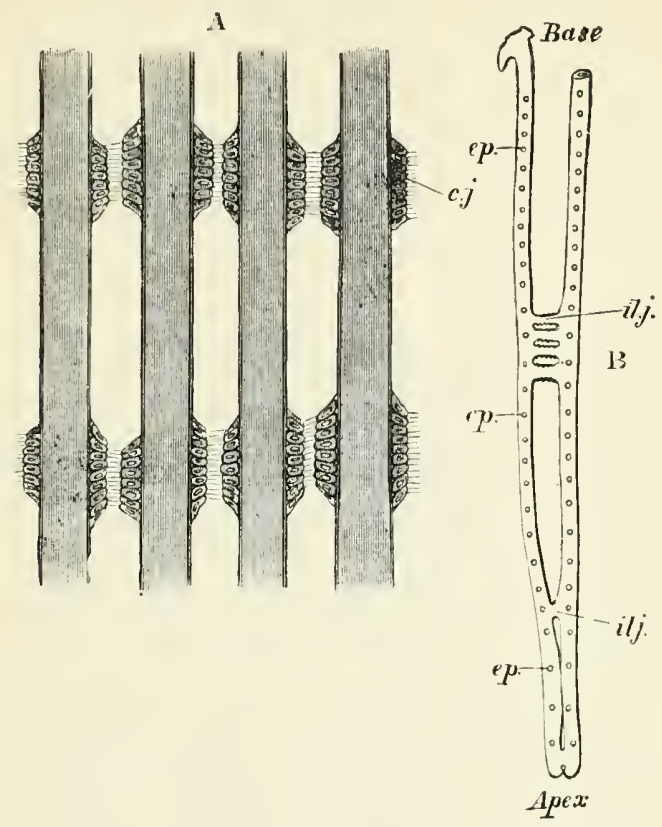

Gill of Mytitus edulis.

A. Part of four filaments showing eiliated interfilamentar junctions $(c . j)$.

B. Diagram of a single filament showing the two lamellae connected at intervals by interlamellar junctions (il.j) and the position of the interfilamentar ciliated junctions $(e p)$.

From the Encyclopaedia Britannica (by permission of Messrs. A. \& C. Black).

formation of junctions between adjacent filaments, so that each series of filaments becomes a double lamella, from the development of interlamellar connexions and from extensive folding of the lamellae themselves. In one group (Septibranchia) the gills are reduced to a muscular septum.

Four orders may be recognized, Protobranchia, Filibranchia, Eulamellibranchia, and Septibranchia. 


\section{Order 1. PROTOBRANCHIA.}

(Case 1:37.)

In the Protobranchia the individual filaments of the gills are not donbled, and are arranged on their axis in two divergent rows. The gills thus have essentially the same structure as those of the Polyplaeophora and the Phipidoglossa. The foot is flattened underneath (another primitive character), and the byssus is but poorly developed. There are only a few families of living forms, of which the Nuculidae (Case 137) are the best known. A number of fossils, ehiefly from the Silurian, have been referred to this group on the evidence of the shell.

\section{Order 2. FILIBRANCHIA.}

\section{(Cases 137 to 153.)}

To the Filibranchia belong some familiar molluses, such as the Seallop and Mussel. In these Lamellibranehs the two rows of filaments in each gill are parallel to each other and their ends are 'refleeted', i. e. the filaments are bent on themselves so as to make a narrow $V$. Each series of filaments, from the gill-axis to the bend, is named the deseending lamella, and from the bend to the tip the ascending lamella. The adjacent filaments are loeked together by tufts of eilia which fit into each other like two hair-brushes pressed together by their bristles. The foot usually exhibits a well-developed byssus.

The Anomiidae are remarkable for a deep noteh in the right valve, through whieh the byssus passes when the animal is fixed down. The Placunidae (Case 13S) have a very flat pearly shell and a unique hinge consisting of two long divergent teeth. The young shells are so transparent that they have been largely used in the East for glazing windows.

The Arcidae have strong ponderous shells with numerous small teeth in the hinge-line. A few of the smaller speeies live on eorals.

The Trigoniidae (Case 141) include a few living species from Australia and more than a hundred forms from Jurassic and Cretaceous strata.

The Mussels (Mytilidae, Cases 142-145) are well known. The byssus is usually well developed; with it the animals attach themselves to rocks or to one another, often forming large eolonies. The coloration of certain Mytilidae is very attractive, rieh brown and green being the prevailing hues (ef. Case 143). The speeies of Lithodomus are not fixed down by a byssus, but burrow into eoral and limestone.

Inoceramus, found fossil in the Jurassic and Cretaeeous, is remarkable for its gigantie size. A species obtained in Nebraska 
measures orer a vard in diamoter. A large specimen may be seen in the Geological Iepartment.

'The Pleriidue include the "Pearl' and 'Hammer' Oysters and the Wing-shells. The Hammer Oysters (Jallews. Case 146) are remarliable for the grotesque shape of the shell, an exaggeration of a tendency seen in Aricula (Case 145), Pleria, and certain species of Margaritifera. Arienla zebra lives on a Hydroid, Halicornaria insigmis, and imitates its colour-markings with remarkable closeness.

The Pearl Orsters (Margarififera) are exhibited in Case 147 and Wall-case D. Species of this gents oceur on the coasts of India, Coylon, and North- West Australia. In the Ceylon pearl fishery 80.000 .000 shells were dredged in 1905. The interior of the shell of these molluses is lined with dense nacre or mother-

Fic. :?9.

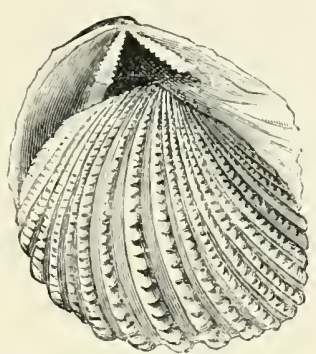

Trigonia margaritacen. Case 141.

From The Cambridge Natural History (by permission of Messrs, Macmillan \& Co.).

of-pearl (v. p. 9), and the isolated pearls found in the tissues of the animal are formed of the same substance. The most important types of pearl are the "orient' and 'muscle' pearls. Orient pearls are by far the most valuable; they are often formed round a parasitic worm that has found its way into the tissues of the mantle. Round this centre of irritation are built up successive layers of nacre mutil an irregular or spherical body is formed. Sometimes the pearl contains another sort of melens, e.g. a sand grain. Inscle pearls, which are usually found in the neighbourhoor of muscles, do not eontain a nucleus of intrusive substance, but are formed round particles of nacre. Such is the origin of most of the small seed-pearls. The well-known Japanese "culture pearls' are produced by grafting into the mantle of a Pearl Oyster small pieces of the mantle (2) ithelimm of another individual, each wrapperl round a small piece of nacre, which serves as a nucleus. 'Blister pearls', which are of no commercial value, are found on the immer surface of the shell. These result from the intrusion of 
foreign bodies between the mantle and the shell, or are seereted over areas invaded by horing animals such as Sponges (Cliona celata) and worms.

The Chinese obtain pearls artifieially from a species of freshwater Mussel (Dipsas plicata). In order to do this they keep them in tanks and insert between the shell and the animal either small shot or small round pieces of mother-of-pearl, which soon receive regular eoatings of nacre and assume the appearance of ordinary pearls. They also insert small metal images of Buddha, which also soon become covered with pearl and firmly cemented to the shell. Specimens illustrating this practice, as well as shells of the Ceylon Pearl Oyster containing small fish and crabs coated orer with nacre, are exhibited in the Pearl Oyster Series (Wall-case F).

The Spondylidac, or Thorny Oysters, elosely resemble the Scallops, but their shells are heavier, more spiny, and united by interlocking teeth; many are very brightly coloured. The Pectinidae, Scallops or Fan-shells, are well known for their beautiful colours and sculpture. The cyes, which are borne on the mantle, approach the Vertehrate eye in complexity. The young move through the water by opening and shutting their valves. The species are numerous and are found at all depths.

\section{Order 3. EULAMELLIBRANCHIA.}

\section{(Cases 153 to 204.)}

The Eulamellibranchia have the gill-plates joined together by vascular interlamellar junctions and very much folded. The edges of the mantle are united at one or two points.

The Oysters (Ostraeidae, C'ase 154) are the most familiar members of this orcler; since early times the cultivation of these animals has been practised in rarious parts of the world. A series of shells of different ages from the "spat" to the adult is shown in Case 154. During the months of May, June, and July, the eggs are discharged into the gills, where they remain until hatched; during this period and until the eggs are hatched in September, Oyster's are "out of season". The Common Oyster passes through a sexual cycle to which reference has been made already (p. 12).

The Japanese Ostraea gigas is said to grow to a length of 3 feet, and some species of Pinna reach a length of 2 feet. The latter are found embedded in sand with the pointed end downwards. The threads of the large silky byssus can be used for weaving or knitting.

The Carditidae and Astartidae (Cases 160, 161) have strong, solid shells, frequently ornamented with radiating or concentric ribbing, and usually coated with a dark epidermis. They have the general appearance of certain Veneridae; the animal has no 
Fig. 30

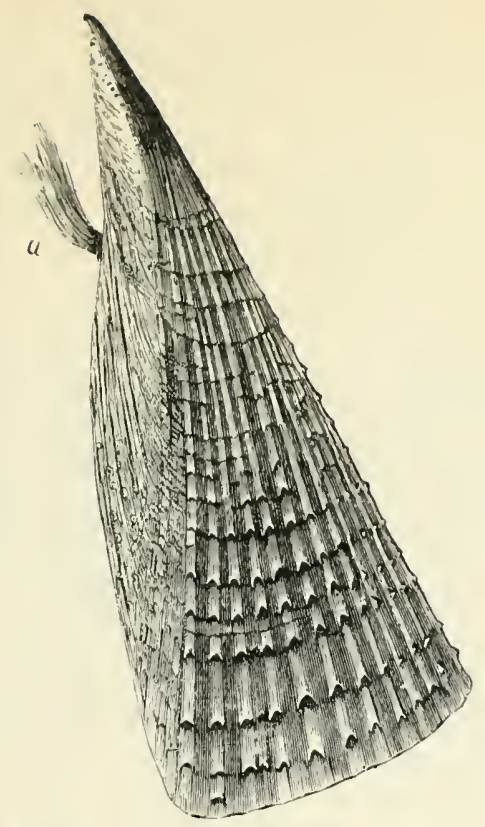

British 'Fan-Mussel' (Pinna peclinala): a. the byssus: Case 157

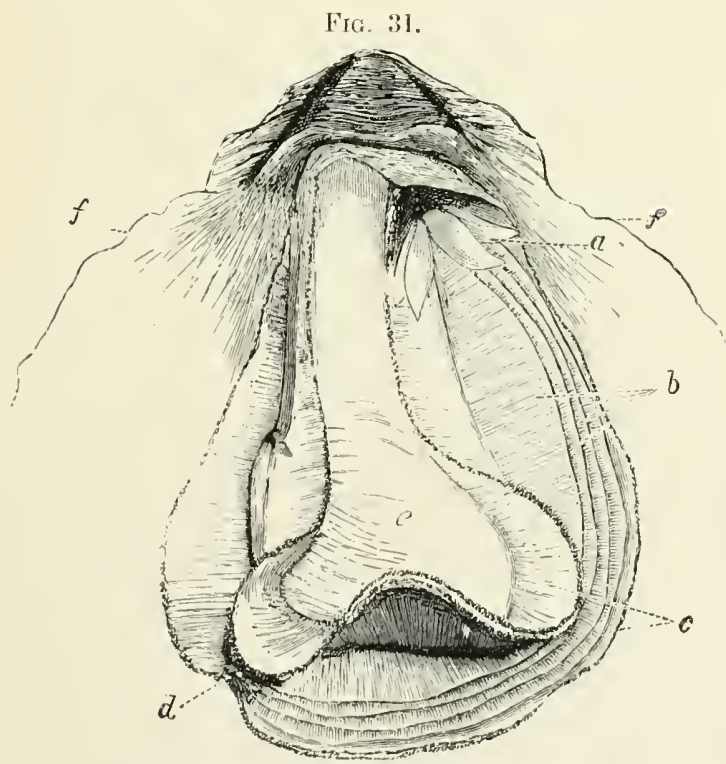

Common Edible Oyster (Ostren adulis).

a. labial palpi ; b. gills ; $c$. mantle ; d. junction of the two folds of the mantle:

e. large adductor muscle; $f$. the shell. 
prolonged siphons, but merely a fringed opening in the mantle. One very remarkable species, Thecalia concamerala (Case 161), has an internal cup-like process within the valves, which serves as a nursing-pouch for the young.

The freshwater Mussels (Unionidue, Cases 166, 167) are an enormous group of over 1,400 living species. They are found in

Fir. :32.
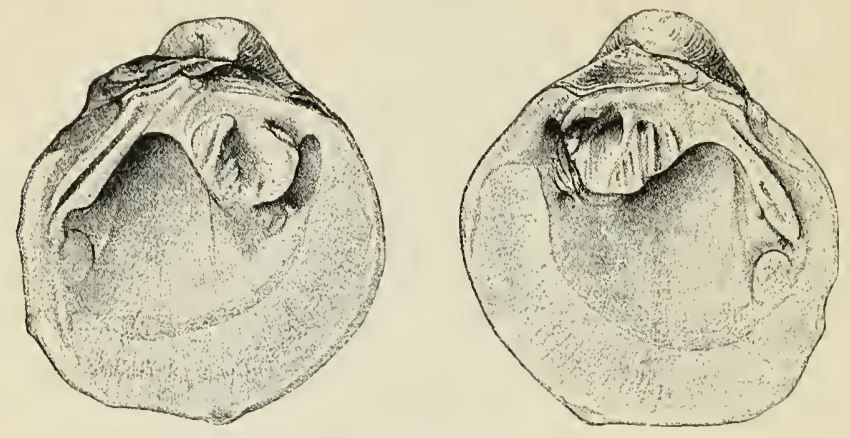

A. Unio graniferus.

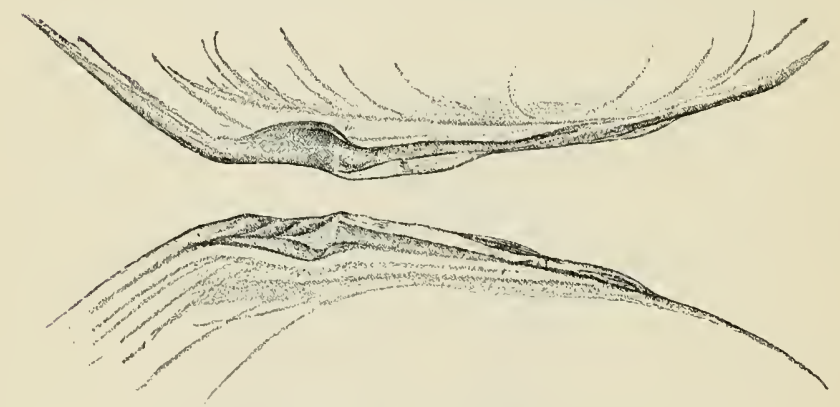

B. Anodonta anatina.

rivers and streams in most parts of the workl, but are most plentiful in North Ameriea, where they are cultivated for commercial purposes (button-making, \&e.). Margarilana margaritifera, which is found in the rivers of this eountry and of Europe, sometimes produces handsome pearls, for which it has been valued since Roman times. Varions types of inenbating chambers are developed in the gills.

The young Mussels of this family escape as larvae known as Glochidia, in which each valve of the shell has a hook at the edge. 
With these hooks a certain number of larvae sueceed in fixing themselves upon fishes, and if they light upon soft tissue such as a gill-filament the irritation of the hook canses the flesh to grow over the Glochidium and to form a cyst round it. The larval Mussel develops within the eyst and lives parasitically on the fish until it is liberated by the breaking up of the eyst.

Fig. 33.

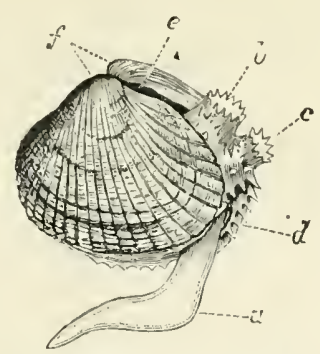

Common British Cockle (Cardium $\mathrm{fdule}$ ).

a. foot; b. exhalant siphon; $c$. branehial or inhalant siphon; $d$. edge of mantle ; $e$. ligament; $f$. mmbones or beaks of the shell.

FiG. 34 .

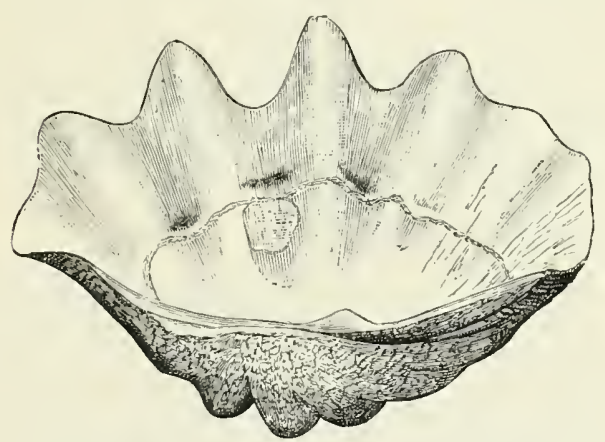

Left valve of the Giant Clam (Tridacna gigas).

Length. 36 inches. Weight, $154 \mathrm{Hb}$. : weight of the two valves, $310 \mathrm{lb}$.

The Tellinidae (Case 179), Veneridae (Case 185), and the Cockles (Cardiidae, Case 192) are all remarkable for the diversity of colour and sculpture that their members exhibit.

An interesting phase of Lamellibranch evolution is found at its maximum among many of the Eulamellibraneh families now to be considered. There is a tendeney in the elass for the mantle edges to beeome fused at one or more points, and the resulting orifices at the posterior end may be very much elongated and 
Fig. 35.

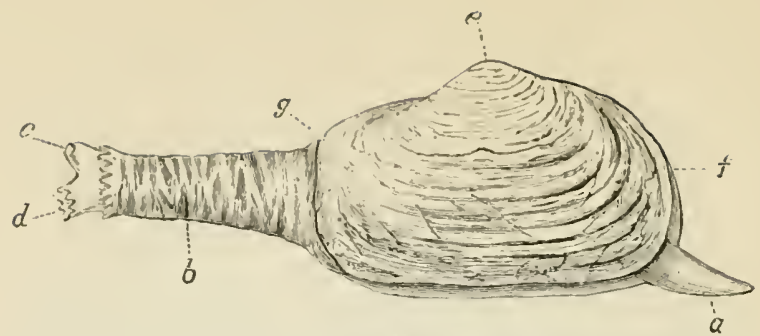

British Gaper (. Hya truncato).

u. toot: $b$. siphon-sheath : $c$. exhalant siphon: $d$. inhalant siphon; $e$. umbones or beaks ; $f$. anterior, $g$. posterior end of shell.

Fig. 36.

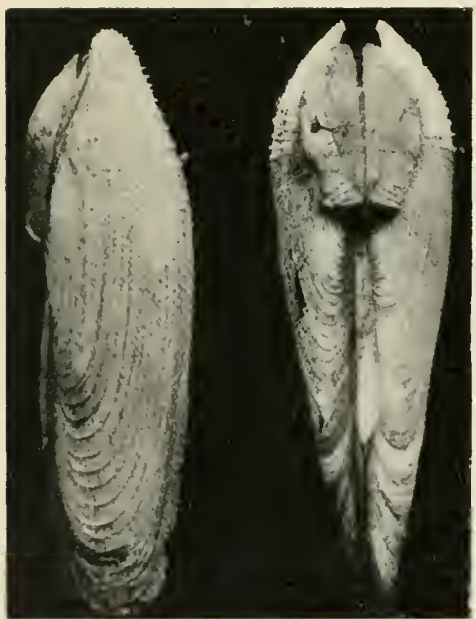

Sliell of Pholus dnctylus.

Side-view on the left showing rows of sharp teeth towards front edge above. Dorsal view on right showing additional plates between the ralves. Redinced.
FIG 37.
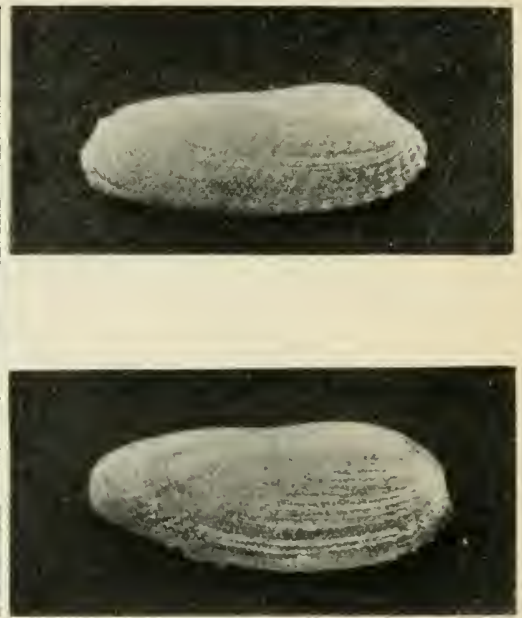

Valves of Pctricola pholadiformis (above), and Pholas candida (below). 
extensible as siphons', which usually act as conduits for the admission of water into the branchial cavity and for the expulsion

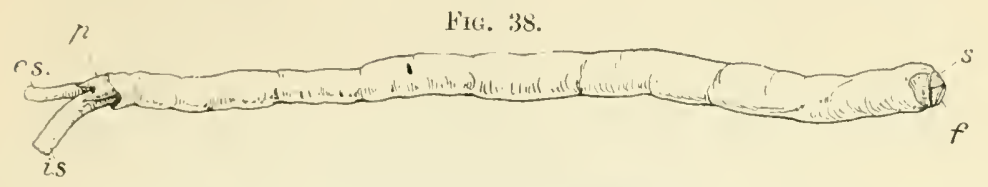

A ship-worm, Teredo nevelis.

c.s. Exhalant siphon. ff. loot. i.s. Inhalant siphon. $t$. One of the pallets. s. (One valve of the shell.

of waste products. Yoldia (among Protobranchs), T'ellina, Psammobia, the I'eneridae, and Teredo (Case 202) are examples of siphonate forms. In Teredo the siphons are enormous and allow the animal to burrow very deeply into wood.

The Tridacnidae (Cases 195, 196) contain the largest living Lamellibranchs, Tridacna gigas, the Giant Clam, sometimes weighing over $500 \mathrm{lb}$.

Many of the Solenidue, or Razor-shells, possess very elongated shells, and are remarkable for the great development of the foot, which can be pointed or contracted as may be required for burrowing into sand. By means of this powerful foot the animals, when disturbed, bore with such rapidity and to such a depth that their capture is a matter of great difficulty.

The Pholadidae, or 'Piddocks', are very remarkable molluses having the power of boring into rock, timber, \&e. The shell is strong and prickly and is used to enlarge the hole as the creature grows. The common Pholas dactylus (Fig. 36) of our own shores has been found in slate-rocks, mica-schist, coal-shale, sandstone, chalk, marl, peat, and wood. These animals are brightly phosphorescent. Certain species are used as food at many places on the shores of the Mediterranean.

The Teredinidae, or ship-worms, are also borers, but do not perforate rocks. They are principally wood-borers, and they cause considerable damage to submarine timber Fia. 39.

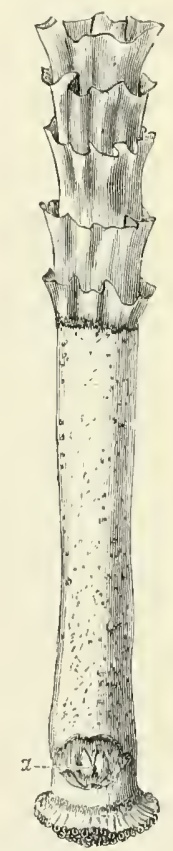

Watering-pot shell (Brechites inginifor). Case 203.

a. bivalve shell of the very young animal. structures.

The habits and structure of these and other wood-and stone- 
boring animals are deseribed in the Guide to Marine Boring Animals and are illustrated in a case in the Central Hall.

'The 'Watcring-pot shell' (Brechites), of the family Clavagellidae, is a long tubular strueture with an expansion at one end. perforated like the rose ' of a watering-pot. It does not represent the shell of an ordinary bivalved molluse, and on looking carefully near the perforated end (" the rose "), two small valves (the true shell) will be seen embeded in the surface. They are found with the 'rose' downwards, buried in mud or sand at low water on the shores of the Indian and Pacific Oceans.

\section{Order 4. SEPTIBRANCHIA.}

(Case 204.)

The septibranchia are a small group in which the gills are transformed into a musenlar partition, which divides the branchial chamber into cloaeal and inhalant portions. The Septibranchia are conneeted with the Eulamellibranchia through such forms as Lyonsia, in which the first steps in the development of muscular tissuc in the gills can be seen. Respiration is effected by the inner surface of the mantle, the muscular septum by its contractions keeping up a continuous stream of water. From the form of the alimentary canal and the eontents of the stomach it is inferred that these animals are carnivorous.

The septibranchia are marine and may be found at great depths. Poromya, Cetoconcha, and Cuspidaria are the best known genera, of which the first and last are found in British waters.

\section{Class V. CEPHALOPODA.}

(Cases 205 to 208.)

The Cephalopoda include the Octopus, Cuttlefish, Squid, Nautilus, \&c. They are Mollusca in which the edges of the foot are divided and extended to form long appendages and are in addition carried forward and joined in front of the mouth, which thus comes to lie in the middle of the foot. A portion of the latter (the epipodium) is expanded into a museular tube, the funnel, by which the water contained in the mantle-eavity is expelled. The animals, which are exelusively marine, move head downwards when on the bottom. The position is ehanged in swimming, as they more with their viseeral sac in front by means of jets of water vigorously expelled from the mantle-cavity through the fumnel. The mouth is usually furnished with a formidable pair of horny beaks (mandibles), and the closely coneentrated nervous ganglia are protected by a cartilaginous sheath. In some members of this class the eye possesses, in addition to a cornca, retina, and lens, a number of accessory 
struetures which render it a very eomplex and effieient organ comparable to that of the Vertebrata. Some of the arms are modified in the male for the purpose of pairing, and in some of the Octopoda the modified tentacle becontes detached.

A striking peculiarity of the class is the elaborate development of chromatophores in certain families. 'Tluese are pigment cells

Fis. 40,
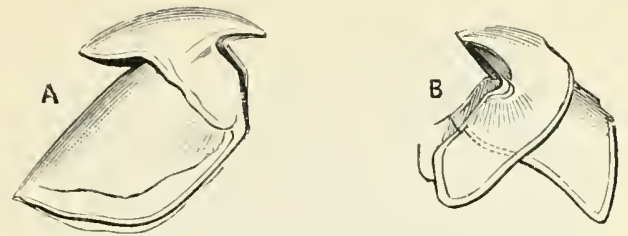

A, the upper, B, the lower beak of Architeuthis monachus; one-third natural size.

FIG. 41.

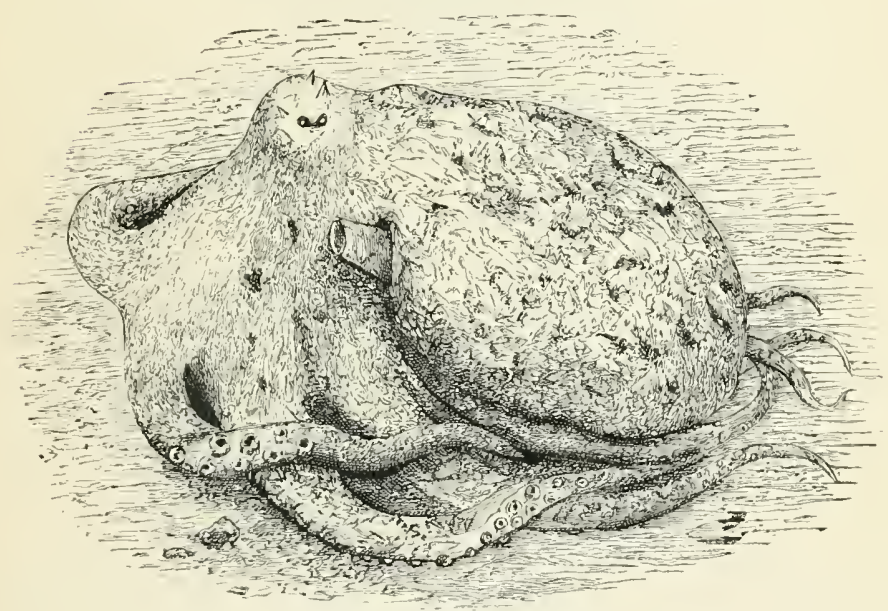

The Common Octopus (Polypus vulyaris), resting.

of varions colours found in the skin and furnished with muscle fibres and a nerve supply. When stimulated by some shock or as the result of direct eontrol by the nervous system the chromatophores of the same colour may all be contracted or extended. The colour of the animal is thus suseeptible to rapid change and may be adjusted for purposes of protection.

All the Cephalopoda are marine, aetive, and camivorons. 'They are divided into two orders-Tetrabranchia and Dibranchia. 


\section{Orter 1. TETRABRANCHIA.}

Vautilus, of which four speeies are known from the IndoPacifie, differs from all other living C'ephalopods in having two pairs of gills instead of one pair, and a large number of small ret ractile tent acles without suckers instead of eight or ten long arms. The shell is external, coiled, and formed of many compartments, of

Iili. 42.

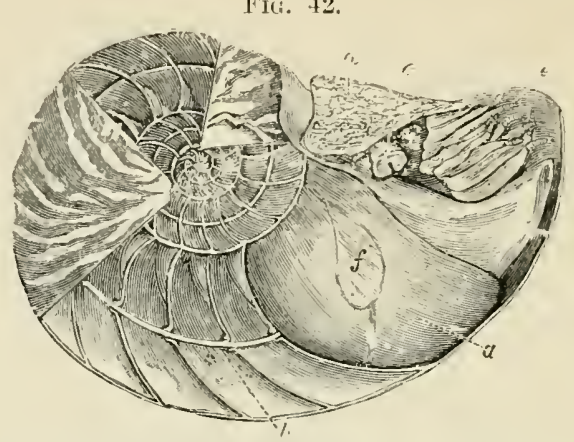

The Pearly Nantilus (Nuutilus pompilius).

a. body : b. siphuncle; $c$. eye; $d$. hood; $e$. tentacles ; $f$. muscle of attacliment to the shell.

FIG. 43.
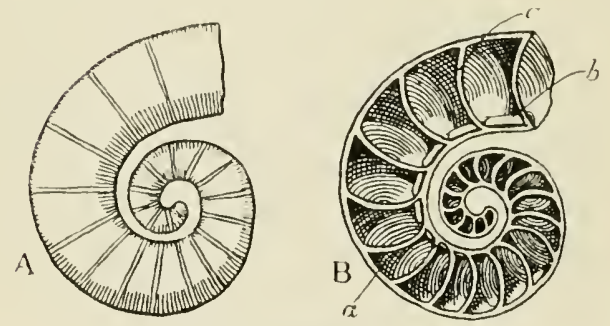

Shell of Spirula peronii.

A. Complete specimen. B. Section of shell showing septa (li) and siphuncle $(b)$.

which only the last is occupied by the animal, although the septa between the compartments are traversed by a shelly tube containing a prolongation of the tissues of the mantle. Nautilus sometimes swims at the surface, but more often crawls about at the bottom in search of small Crabs, molluses, \&c., on which it feeds. According to Dr. Willey, who studied its habits in the Western Pacific, it is gregarious and nocturnal in its activities. The fossils known as Ammonites are shells similar in structure to that of Nautilus, and they are placed in this order. 


\section{Order 2. DIBRANCHIA.}

The members of this order have a single pair of gills and eight or ten sucker-bearing arms. The shell may be coilod and manychambered, as in the living Spirula, where it is almost wholly internal. In many fossil forms it is straight, and the chambered shell (phragmocone) dwindles and is replaced by secondary caleareous structures which lead to the calcareous "cuttlefishbone 'of the living Sepia and the horny 'pen ' of Loligo and other

Fia. 44 .

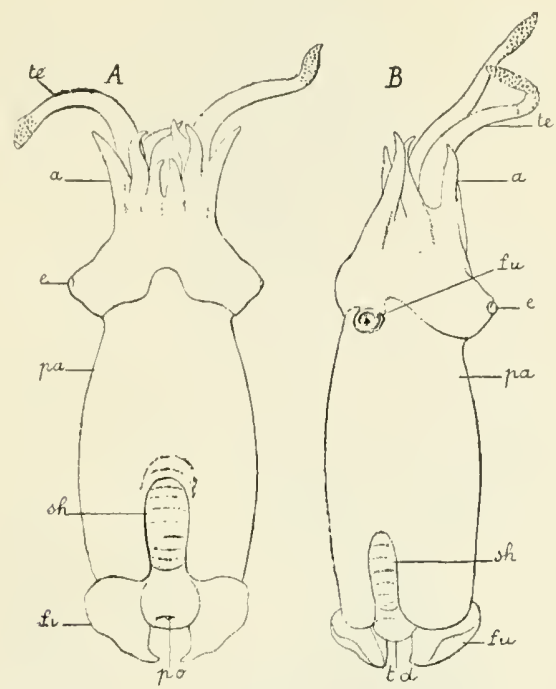

Spirula. Dorsal aspect(A), ventral aspeet(B). sh. shell; e. eye; $f u$. funnel; fi. fins.

From Lankester's Treatise on Zoology (by permission of Messrs. A. \& C. Black)

genera. Finally, in the Octopus (Polypus) the only vestiges of the shell are small chitinous stylets.

The Dibranchia are divided into two sub-order's-Decapoda and Octopoda.

The Decapoda have ten arms, the suckers on which are strengthened by horny rings which may bear hooks; two of the arms are retractile into special pouehes and are known as "tentacular arms'.

Some living Decapocls attain a great size, e.g. Architeuthis, of which a model is suspended from the ceiling of the Gallery. 'There can be little doubt that some tales of 'Sea-scrpents' are based on the appearance of such monsters. Complete examples 
of Spirula (Case 207, Wall-case G) were for a time among the greatest rarities in zoological eolleetions, though the shell is to be obtained in large quantities on tropical and sub-tropical shores.

Fis. 45.

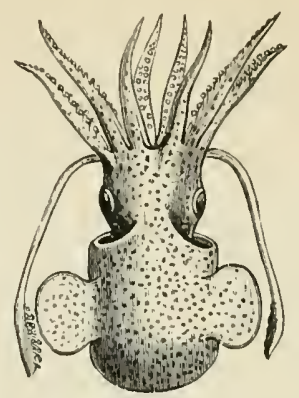

Sepiola scandica (natural size). British.

FIG. 46.
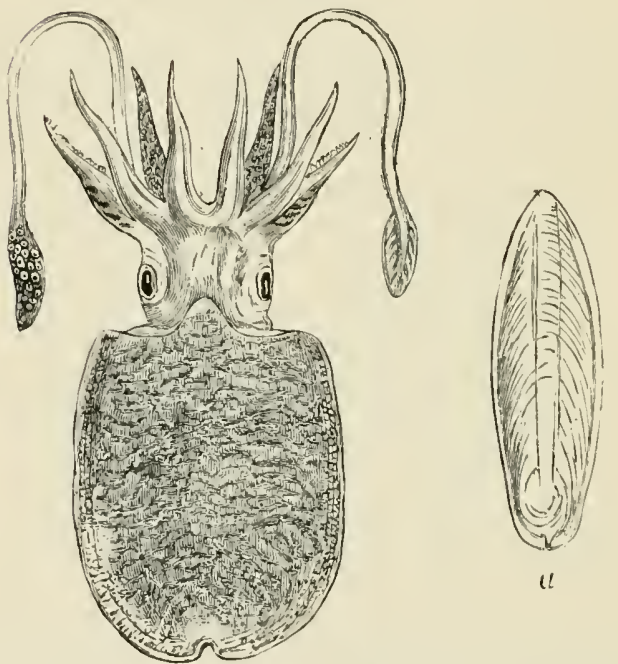

The Common Cuttlefish (Sepia officinalis), and its shell or 'bone' $(\tau)$.

Quite recently, however (1922), the living animal has been taken in large numbers by a Danish Occanographical expedition off the West Indies and in the Atlantic Ocean.

Great variety of shape and colour is found, and the development of lateral fins adds to the general diversity of form among the 
Decapoda. Doratopsis, Chiroteuthis, Ommastrephes, and Cranchia (in which the arms are very short and the body is swollen and globular) are among the most striking genera. Some of the abyssal or deep-sea Decapoda are distinguished by the presence of remarkable luminous organs, which are borne on the mantle or near the eyes. In Bathothauma and Toxeuma the eyes are very large and are carried on long stalks.

Fic. 47.

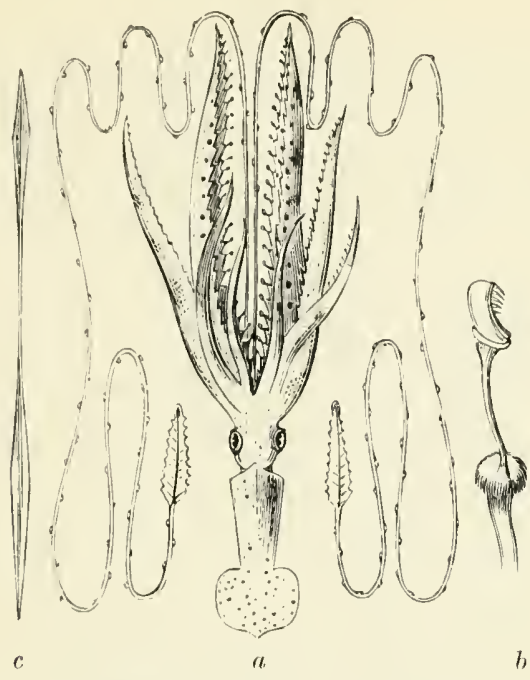

Chiroteuth is veranyi (much reduced).

a. general view of animal; $b$. magnified view of peduneulated sucker of the terminal club of the tentacular arms : $c$. internal shell or gladius.

The Octopoda have eight arms and the body is rounded and short. The morlel of a large Polypus punctatus is suspended from the roof of the Gallery. The Paper-Nautilus (Argonauta) is remarkable in that the female seerctes a special shell from the two dorsal arms, which serves as a brood-chamber (Wall-case G). 



\title{
ALPHABETICAL INDEX
}

\author{
OF THE
}

\section{PRINCIPAL FAMILIES AND GENERA OF MOLLUSCA EXHIBITED IN THE SHELL GALLERY.}

This Index has been compiled to assist the numerous visitors, who wish to examine and determine specimens of shells, in finding, without trouble or loss of time, the Cases in which the genera are placed. Subgeneric terms are omitted, as they do not fall within the scope of this 'Guide '.

\begin{tabular}{|c|c|c|c|c|c|}
\hline Acanthina & $\begin{array}{r}\text { CASE } \\
75\end{array}$ & Bulimus $=$ Stro & CASE & & $\begin{array}{r}\text { CASE } \\
127\end{array}$ \\
\hline Achatina & 130,131 & phocheilus & 120 & $\begin{array}{l}\text { Cylinareila } \\
\text { Cypraea }\end{array}$ & $\begin{array}{r}127 \\
32-5\end{array}$ \\
\hline Achatinella. & $.134,135$ & Bullidae & 95 & Cyprina $=$ Arc & 162 \\
\hline $\begin{array}{l}\text { Acmaea } \\
\text { Actaeon }\end{array}$ & $\begin{array}{r}4 \\
94\end{array}$ & & & tica & \\
\hline $\begin{array}{l}\text { Actaeon } \\
\text { Aetheria }\end{array}$ & $\begin{array}{r}94 \\
178\end{array}$ & Calyptraeidae & - 31,32 & Cyrena - d & 164 \\
\hline $\begin{array}{l}\text { Aetheria } \\
\text { Amphibola }\end{array}$ & $\begin{array}{r}178 \\
98\end{array}$ & $\begin{array}{l}\text { Cancellaria. } \\
\text { Capulus. }\end{array}$ & $\begin{array}{l}77 \\
31\end{array}$ & $\begin{array}{l}\text { Cythera }=\text { Mere }- \\
\text { trix }\end{array}$ & 185 \\
\hline Amphiperas & 35 & Cardita. & 160 & & \\
\hline Ampullaria. & 25,26 & Cardium & $192-4$ & Delphinula . & 12 \\
\hline Amussium . & 159 & Carinaria & 94 & Dentalium . & 136 \\
\hline Anatina. & 203 & Cassis . & 55,56 & Despoena . & 22 \\
\hline Ancylus. & $\begin{array}{r}99 \\
\text {. }\end{array}$ & Cerion . & 129 & Diplodonta . & 163 \\
\hline Anodonta & $.166,167$ & Corithiidae . & $42-4$ & Dolium = Tonna & 56,57 \\
\hline Anomia . & - $\quad 137$ & Chaetoderma & 3 & Donax . . & 182 \\
\hline Anostoma & 128 & Chama . & 196 & Dosinia . & 188 \\
\hline Aplacophora & 3 & Chitonidae . & $1-3$ & Dreissensia . & 179 \\
\hline Aplustrum . & 96 & Chrysodomus & 64 & & \\
\hline Aplysia =Tethy & 96 & Circe ... & 187 & Eburna & 67 \\
\hline Aporrhais . & 49 & Clausilia . & 129,130 & Emarginula & 7 \\
\hline Arca & 139 & Clavagella $=$ & 204 & Énnea . & 103 \\
\hline Arctica . & $\cdot \quad 162$ & Bryopa & 69 & Eolis : . & 97 \\
\hline $\begin{array}{l}\text { Argonauta . } \\
\text { Arion . }\end{array}$ & $\begin{array}{r}205,206 \\
107\end{array}$ & $\begin{array}{l}\text { Columbella . } \\
\text { Conus : }\end{array}$ & $89-94$ & Eucalodium & 129 \\
\hline Aspergillum & 204 & Coralliophila & 76 & Eulima . & 46 \\
\hline (= Brechites) & $20 t$ & Corbicula . & 164 & Fasciolaria & \\
\hline Astarte & 161 & Corbis . & 163 & $\begin{array}{l}\text { Fasciolaria } \\
\text { Ficula = Piru }\end{array}$ & 59 \\
\hline $\begin{array}{l}\text { Atlanta } \\
\text { Auriculidae. }\end{array}$ & 94 & Corbula. & 198 & $\begin{array}{l}\text { Ficula }=\text { Firu } \\
\text { Fissurella }\end{array}$ & $\begin{array}{r}57 \\
8\end{array}$ \\
\hline $\begin{array}{l}\text { Auriculidae } \\
\text { Avicula }=\text { Pteria }\end{array}$ & 97,98 & Crassatella. & 161 & Fulgur. & 61 \\
\hline Avicula = Pteria & 145 & $\begin{array}{l}\text { Crenatula } \\
\text { Crenella. }\end{array}$ & $\begin{array}{l}147 \\
145\end{array}$ & Fusus & 57,58 \\
\hline Batissa . & 165 & Cucullaea & 140 & & \\
\hline Brechites & 204 & Cum & 75 & Gadinia. & 99 \\
\hline Bryopa . & 204 & Cuspidaria & 204 & Galatea. & 165 \\
\hline Buccinum & 65 & Cyclophoridae & 23,25 & Galeomma . & 163 \\
\hline Buliminus & 128 & Cyclostomatid & 28,29 & Gastrochaena & 201 \\
\hline Bulimulus & 122 & $=$ Pomatiida & & Gena & 11 \\
\hline
\end{tabular}




\begin{tabular}{|c|c|c|c|c|c|}
\hline & & & & & \\
\hline Glandina = & ) & Montacuta. & 163 & Planorbis & 100 \\
\hline Oleacina & 102 & Murex. & $70-3$ & Pleurotomaria & 9 \\
\hline Gilaneonome & 192 & Mutela. & 177 & Pleurotomidae & 1 \\
\hline (ilycymeris. & $1+1$ & Муа. . & $19 \mathrm{~s}$ & =Turrilae & $55-7$ \\
\hline & & Mratora & 203 & Plicatula. & 154 \\
\hline Haliotis. & $9-11$ & Mreetopus . & 176 & Pomatiidae. & 28,29 \\
\hline Haminea & 9.5 & Myochama. & 203 & Proseryina $=$ & ( \\
\hline Harpa. & 84 & Mytilus. & $.142,143$ & Despoena & \} \\
\hline Helicarion . & 104 & & & Psammobia & 197 \\
\hline Helicidae. & . $107-21$ & Nassa . & 67.68 & Pteria . & 145 \\
\hline Helicina & . 21 & Naticidac & 36,37 & Pterocera & 51,52 \\
\hline Hemifusus . & 61 & Nautilus . & 208 & Pteropoda. & 96 \\
\hline Heteropoda & 57 & Navicella = & 1 & Puncturella. & . \\
\hline Hinnites . & 159 & Septaria & \} & Pupa . . & 120 \\
\hline Hydatina & 96 & $\begin{array}{l}\text { Neaera }=\text { Cus } \\
\text { pidaria }\end{array}$ & 204 & $\begin{array}{l}\text { Purpura }= \\
\text { Thais.s }\end{array}$ & 74.75 \\
\hline Ianthina & 38 & Neomenia & & Pyramidellidae & 45 \\
\hline Isocardia . & 162 & Nerita. & 18,19 & & \\
\hline $\begin{array}{l}\text { Isognomon }= \\
\text { Melina }\end{array}$ & 147 & $\begin{array}{l}\text { Neritina }= \\
\text { Theodoxis }\end{array}$ & $\bigcap_{1} 19.20$ & & ; \\
\hline & & Nucula. & I37 & trum & \} \\
\hline Kellia & 163 & Nuculana . & 137 & Ringicula & $9 \tilde{z}$ \\
\hline & & Nudibranchiat & & Risse & \\
\hline Latiaxis & 74 & & & Rocellaria & 201 \\
\hline atirus : & ; & Octopus = Po- & & Rostellaria . & \\
\hline $\begin{array}{l}\text { dana } \\
\text { lanacu }\end{array}$ & 137 & lури & \{ & Rotella. & 15,16 \\
\hline $\begin{array}{l}\text { lana } \\
\text { Lepeta }\end{array}$ & . & Oleacina & 102 & & \\
\hline epton. & 163 & Oli & $81-3$ & Saxicara & 201 \\
\hline Lima . & 156 & astrephes & 15207 & Scala . & 44.45 \\
\hline Limax . & . $\quad 106$ & $\dot{m}=\dot{A m}$. & & Scalaria $=$ Epi- & 44,45 \\
\hline Limnaeidac & . 99-102 & phiperas & 35 & tonium & 1 \\
\hline Limopsis . & . $\quad 141$ & & & Scaphander & 95 \\
\hline Lithodomus & 144 & & & opoda & 136 \\
\hline Littorina . & 27 & Paludina $=$ & & Scintilla . & 163 \\
\hline lic & . $\quad 207$ & para & j & $\mathrm{m}$. & 7 \\
\hline Lucinidae & $.162,163$ & Paludomus. & 41 & le. & . 181 \\
\hline Lutraria & . 199 & Pandora. & 202 & & 206,207 \\
\hline Lyonsia & 203 & Panopea & 201 & aria & . 20,21 \\
\hline & & & $.126,127$ & & 143 \\
\hline Lactridae & $183-5$ & Patel & . $\quad 4-7$ & uria & 47 \\
\hline 1 & 77 & Pectinidae . & $156-60$ & naria & 98,99 \\
\hline Malletia. & 137 & Pectunculus = & 1 & Sistrum. . & 76 \\
\hline & 146 & meris & $i$ & & 45 \\
\hline nella. & 83,84 & Pedt & 156 & Solenidae & $.199-201$ \\
\hline Melaniidae $=$ & 1 & Periploma & 203 & Solenomya. & 137 \\
\hline Tiaridae & $3 S-41$ & eola & 192 & Sphaerinim . & $16 \bar{J}$ \\
\hline Meleagrina . & 146 & e. & & 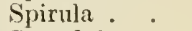 & 207 \\
\hline Meli & 147 & Plıoladidae & $.201,202$ & pondylus & $154-6$ \\
\hline Melongena . & 61 & Pholadomỵa & - 204 & Stenogyra . & 133 \\
\hline Meretrix . & 185 & as . & $.201,202$ & Stilifer . & 46 \\
\hline esma & 18 & Phorus (= & & Stomatella & 11 \\
\hline Mitridae . & . $\quad 61-4$ & Xenophora) & & Streptaxis & 102 \\
\hline Modiola. & $.143,144$ & Physa . . & 101 & Strombus . & $49-51$ \\
\hline & . 145 & I & . $148-52$ & Strophia= & \\
\hline Modiolaria . & 145 & Pirula . & 57 & Cerion & \} \\
\hline Mono & 75 & Placuna. & 138 & Strophocheilus & 120 \\
\hline Acanthina & 10 & Planaxis . & 44 & Struthiolaria & 49 \\
\hline
\end{tabular}




\begin{tabular}{|c|c|c|c|c|c|}
\hline & CASE & & CASE & & CASI \\
\hline Succinea & 135 & Triton $=$ & $-2=1$ & Valvata. & \\
\hline Sunetta & 187 & Cymatium & 03,04 & Vanicoro & \\
\hline Sycotypus & 61 & Trochidae & $12-15$ & Velutina & \\
\hline & & Trophon & 70 & Veneridae & $185-$ \\
\hline Tapes . & $.190,191$ & Truncatella. & 30 & Venerupis & 19 \\
\hline Tcllinidae & . $179-81$ & Tugohia. & 198 & Venus & \\
\hline Terebellum . & . $\quad 52$ & Turbinellidae & 60,61 & Vermetidae. & 46,47 \\
\hline Terebridae & $87-9$ & 'Turbinidae . & $16-18$ & Vitrina . & \\
\hline Teredo. & 202 & Turritella & 48 & Vivipara & \\
\hline Testacella & 102 & Typhis . & 70 & Volutidac & $78-8$ \\
\hline Tethys . & 96 & & & Vulsella & \\
\hline Thracia . & 203 & & & & \\
\hline Tonna . & 56,57 & Umbraculum = & & Xenophora & \\
\hline Trichotropis & 37 & Umbrella & $\hat{i}$ & Xesta. & \\
\hline Tridacna & 195 & Ungulina . & . $\quad 163$ & & \\
\hline Trigonia & 141 & Unionidae . & . $166-78$ & Yoldia & \\
\hline
\end{tabular}






\section{BRITISH IIUSEUII (NATURAL HISTORY).}

\section{DAYS AND HOURS OF ADMISSION.}

The Museum is open to the Public, free dailyon WEEK-DAYs, throughout the year from 10 a.m., in January and February . . to 5 p.m. Narch to September (inclusive) " 6 "

October, November and December " 5 " on Sundays, throughout the year from 2.30 to 6 p.m. The Museum is closed on Good Friday and Christmas Day.

By Order of the Trustees,

S. F. HARMER,

Director. 
"I British liuseum (Natural History) 406 Dept. of Zoology

E82 Guide to the Mollusca

Bioliea

\section{UNIVERSITY OF TORONTO LIBRARY}


